\title{
Hematopoietic chimerism and central tolerance created by peripheral-tolerance induction without myeloablative conditioning
}

\author{
Edward Seung, ${ }^{1}$ John P. Mordes, ${ }^{2}$ Aldo A. Rossini, ${ }^{1,2,3}$ and Dale L. Greiner ${ }^{1,2}$ \\ ${ }^{1}$ Program in Immunology and Virology, \\ ${ }^{2}$ Department of Medicine, and \\ ${ }^{3}$ Department of Molecular Medicine, University of Massachusetts Medical School, Worcester, Massachusetts, USA
}

\begin{abstract}
Allogeneic hematopoietic chimerism leading to central tolerance has significant therapeutic potential. Realization of that potential has been impeded by the need for myeloablative conditioning of the host and development of graft-versus-host disease (GVHD). To surmount these impediments, we have adapted a costimulation blockade-based protocol developed for solid organ transplantation for use in stem cell transplantation. The protocol combines donor-specific transfusion (DST) with anti-CD154 mAb. When applied to stem cell transplantation, administration of DST, anti$\mathrm{CD} 154 \mathrm{mAb}$, and allogeneic bone marrow leads to hematopoietic chimerism and central tolerance with no myeloablation and no GVHD. Tolerance in this system results from deletion of both peripheral host alloreactive $\mathrm{CD}^{+} \mathrm{T}$ cells and nascent intrathymic alloreactive $\mathrm{CD}^{+} \mathrm{T}$ cells. In the absence of large numbers of host alloreactive $\mathrm{CD}^{+} \mathrm{T}$ cells, the transfusion that precedes transplantation need not be of donor origin, suggesting that both allospecific and non-allospecific mechanisms regulate engraftment. Agents that interfere with peripheral transplantation tolerance impair establishment of chimerism. We conclude that robust allogeneic hematopoietic chimerism and central tolerance can be established in the absence of host myeloablative conditioning using a peripheral transplantation tolerance protocol.
\end{abstract}

J. Clin. Invest. 112:795-808 (2003). doi:10.1172/JCI200318599.

\begin{abstract}
Introduction
Allogeneic stem cell transplantation has significant potential for the treatment of malignancy (1), autoimmunity (2-5), and genetic disorders $(6,7)$. It can also be used to facilitate gene therapy (8-12) and solid organ transplantation $(13,14)$. Realization of that potential has been difficult, however, because of significant patient-safety issues (15). Achieving allogeneic hematopoietic chimerism currently requires preparative conditioning with immunosuppression and at least partial myeloablation (15). The conditioning required to establish stem cell engraftment is toxic, and even in partially ablated recipients, stem cell transplantation almost invariably leads to some degree of graft-versus-host disease (GVHD) (13, 14, 16-18). GVHD generally requires treatment with immunosuppressive drugs, which have many toxic side effects (19). Both the conditioning regimen and immuno-
\end{abstract}

Received for publication April 9, 2003, and accepted in revised form July 3, 2003

Address correspondence to: Dale L. Greiner, Diabetes Division, University of Massachusetts Medical School, Two Biotech, 373 Plantation Street, Suite 218, Worcester, Massachusetts 01605, USA. Phone: (508) 856-3800; Fax: (508) 856-4093; E-mail: dale.greiner@umassmed.edu.

Conflict of interest: The authors have declared that no conflict of interest exists.

Nonstandard abbreviations used: graft-versus-host disease (GVHD); donor-specific transfusion (DST); T cell receptor (TCR); Desire (DES). suppressive medications pose short-term risks of infection and longer-term risks of malignancy (20).

To avoid both lethal conditioning and GVHD, new strategies based on costimulation blockade are being developed. The combination of sublethal host conditioning and costimulation blockade has been shown to lead to the generation of allogeneic hematopoietic chimerism in mice $(18,21-27)$. Tested approaches include sublethal irradiation plus CTLA4-Ig and/or anti-CD154 mAb with or without peripheral $\mathrm{T}$ cell depletion $(22,23,26)$; anti-CD154 mAb plus druginduced myeloablation $(25,28)$; and injection of supraphysiological doses of bone marrow over an extended time in combination with anti-CD154 mAb without host conditioning $(27,29)$. Hematopoietic chimerism generated in these systems involves intrathymic deletion of host $\mathrm{V} \beta \mathrm{CD} 4^{+} \mathrm{T}$ cells reactive to donor superantigens presented by donor MHC class II I-E antigens; this result suggests that a state of central tolerance has been induced $(18,30)$. Preexisting peripheral host V $\beta$ donor-reactive $\mathrm{CD}^{+} \mathrm{T}$ cells appear to die over time through both Fas-dependent and independent mechanisms (23). A single trial of allogeneic stem cell transplantation for the treatment of leukemia based on ex vivo blockade of B7-mediated costimulation reportedly showed promising results (31).

In the field of organ transplantation, the therapeutic potential of allogeneic hematopoietic chimerism resides in its ability to generate central tolerance, which is the most robust state of donor-specific 
transplantation tolerance known $(13,18,32)$. To translate this potential into clinical reality, we have attempted to discover optimal conditioning regimens that shorten the treatment period, eliminate the need for host myeloablative conditioning, and lead to allogeneic hematopoietic chimerism in the absence of GVHD. These attempts are based on strategies originally developed for the generation of peripheral transplantation tolerance (13).

Costimulation blockade-based protocols are very effective for inducing peripheral transplantation tolerance (13). Our laboratory uses a donor-specific transfusion (DST) to activate alloreactive T cells and simultaneous blockade of CD40-CD154 interaction using an anti-CD154 mAb (13). This protocol induces permanent survival of pancreatic islet allografts in mice (33) and prolonged survival of skin allografts in both mice (34-36) and nonhuman primates (37). The mechanism of peripheral transplantation tolerance induction based on DST plus anti-CD154 mAb involves the action of IFN- $\gamma$, CTLA4, regulatory $\mathrm{CD}^{+} \mathrm{T}$ cells, and the deletion of alloreactive $\mathrm{CD} 8^{+} \mathrm{T}$ cells $(35,38)$.

We $(21)$ and others $(39,40)$ have shown that stem cell engraftment in mice can be enhanced by injection of a depleting anti-CD8 $\mathrm{mAb}$. Because our peripheral-tolerance protocol using DST plus anti-CD154 mAb leads to specific deletion of alloreactive $\mathrm{CD}^{+} \mathrm{T}$ cells, we hypothesized that the induction of peripheral tolerance by treatment with DST plus anti-CD154 mAb would facilitate stem cell engraftment and the generation of hematopoietic chimerism leading to establishment of central tolerance.

In the present study, we tested this hypothesis using our costimulation blockade-based protocol for peripheral transplantation tolerance (DST plus anti-CD154 $\mathrm{mAb}$ ) with no host myeloablative conditioning. We document that this protocol leads to stem cell engraftment, generation of hematopoietic chimerism, and development of central tolerance in the absence of GVHD. Analysis of the underlying mechanisms revealed that both allospecific and non-allospecific regulatory pathways are important.

\footnotetext{
Methods

Animals. C57BL/6 $\left(H 2^{b}\right), \mathrm{BALB} / \mathrm{c}\left(H 2^{d}\right), \mathrm{CBA} / \mathrm{JCr}\left(H 2^{k}\right)$, and B10.BR $\left(H 2^{k}\right)$ mice of either sex were obtained from the National Cancer Institute (Frederick, Maryland, USA). To investigate the fate of specific alloreactive $\mathrm{CD}^{+} \mathrm{T}$ cells, we established in our animal colony the KB5 T cell receptor (TCR) transgenic mouse, which has specificity to native $\mathrm{H} 2^{\mathrm{b}}$ alloantigen $(41,42)$. This TCR transgenic mouse was the generous gift of John Iacomini (Harvard Medical School, Boston, Massachusetts, USA), who obtained it from the original developer, Andrew Mellor (Medical College of Georgia, Augusta, Georgia, USA). The TCR transgene is expressed by $\mathrm{CD}^{+}$ cells in CBA $\left(H 2^{k}\right)$ mice and has specificity for $\mathrm{H} 2-\mathrm{K}^{\mathrm{b}}$. These transgenic $\mathrm{T}$ cells express a TCR that is recognized by the anti-clonotypic mAb Desire (DES) (41).
}

All animals were certified to be free of Sendai virus, pneumonia virus of mice, murine hepatitis virus, minute virus of mice, ectromelia, lactate dehydrogenase-elevating virus, GD7 virus, Reo-3 virus, mouse adenovirus, lymphocytic choriomeningitis virus, polyoma, Mycoplasma pulmonis, and Encephalitozoon cuniculi. Animals were housed in microisolator cages and given ad libitum access to autoclaved food and acidified water. They were maintained in accordance with the guidelines of the Institutional Animal Care and Use Committee of the University of Massachusetts Medical School and recommendations in the National Academy of Science's Guide for the Care and Use of Laboratory Animals.

Antibodies and flow cytometry. FITC-conjugated anti-H2- $\mathrm{K}^{\mathrm{b}}$ (clone AF6-88.5), phycoerythrin-conjugated anti-H2- $\mathrm{K}^{\mathrm{k}}$ (clone 36-7-5), and phycoerythrinconjugated anti-H2- $\mathrm{K}^{\mathrm{d}}$ (clone SF1-1.1) mAb's were obtained from Pharmingen (San Diego, California, USA). MR1 hamster anti-mouse CD154 mAb was produced as ascites in scid mice, purified using a Protein A-Sepharose 4 Fast Flow purification column (Pharmacia Biotech), and quantified by OD $(43,44)$. Antibody concentration was determined by measurement of OD and confirmed by ELISA (43). The concentration of contaminating endotoxin was determined commercially (Charles River Laboratories, Wilmington, Massachusetts, USA) and was uniformly less than $10 \mathrm{U} / \mathrm{mg}$ of $\mathrm{mAb}$ (43).

Anti-CD4 (GK1.5), anti-CD8 (2.43), and anti-CD25 (PC61.5.3) antibodies were obtained from the American Type Culture Collection (Rockville, Maryland, USA). Antibodies for in vivo depletion were produced as ascites in scid mice and purified using a Protein G PLUS purification column (Oncogene Research Products, Boston, Massachusetts, USA). To deplete $\mathrm{CD}^{+}$and $\mathrm{CD}^{+}$cells in vivo, mice were injected intraperitoneally with $0.5 \mathrm{mg}$ of $\mathrm{mAb}$ on 3 consecutive days. To deplete $\mathrm{CD} 25^{+}$cells in vivo, mice were injected once intraperitoneally with $0.25 \mathrm{mg}$ of the mAb. A hybridoma cell line secreting hamster anti-mouse CTLA4 mAb (clone 9H10) was the gift of James Allison (University of California, Berkeley, California, USA). Anti-CTLA4 $\mathrm{mAb}$ was grown as ascites, purified using a Protein A column (Oncogene Research Products), and injected intraperitoneally at a dose of $0.075 \mathrm{mg}$ per mouse daily on 3 consecutive days. The KB5-specific clonotypic DES antibody was produced from a mouse hybridoma cell line given to us by John Iacomini. FITC-conjugated anti-mouse IgG2a developing reagent for DES (clone R19-15) was obtained from Pharmingen.

Flow microfluorometry was performed as described previously $(21,22,43)$. Briefly, $1 \times 10^{6}$ viable cells were reacted with the appropriate antibody for 20 minutes at $4^{\circ} \mathrm{C}$. In experiments using the $\mathrm{KB} 5$ synchimeras, cells were reacted with anti-DES antibody for 20 minutes at $4{ }^{\circ} \mathrm{C}$. Cells were then washed and reacted with FITC-conjugated anti-mouse IgG2a 
$\mathrm{mAb}$ (to develop the DES antibody). Whole blood was processed using FACS lysing solution (BD Biosciences, Becton, Dickinson, and Company, San Jose, California, USA) in accordance with the protocol supplied by the manufacturer. Labeled cells were washed, fixed with $1 \%$ paraformaldehyde-PBS, and analyzed using a FACScan instrument (Becton Dickinson Immunocytometry Systems, San Jose, California, USA). Lymphoid cells were gated according their light-scattering properties, and $30 \times 10^{3}$ to $50 \times 10^{3}$ events were acquired for each analysis.

The relative percentages of host- and donor-origin cells in the various recipients of $\mathrm{C} 57 \mathrm{BL} / 6\left(\mathrm{H} 2-\mathrm{K}^{\mathrm{b}+}\right)$ bone marrow were determined by flow microfluorometry. The percentage of PBMCs in chimeric mice expressing MHC class I was determined by dual labeling with anti- $\mathrm{H} 2-\mathrm{K}^{\mathrm{b}}$ (donor) and anti- $\mathrm{H} 2-\mathrm{K}^{\mathrm{d}}$ or anti$\mathrm{H} 2-\mathrm{K}^{\mathrm{k}}$ (recipient) antibodies. Because fewer than 100\% of hematopoietic cells express MHC class I antigen, the relative percentage of donor-origin cells $\left(\mathrm{H} 2-\mathrm{K}^{\mathrm{b}+}\right)$ in chimeric recipients was calculated as follows:

\section{Equation 1}

$\left[\% \mathrm{H}_{2}-\mathrm{K}^{\mathrm{b}+} / \% \mathrm{H} 2-\mathrm{K}^{\mathrm{b}+}+\% \mathrm{H} 2-\mathrm{K}^{\mathrm{k}+\text { or d+ }}\right] \times 100 \%$

In previous experiments, known mixtures of $\mathrm{BALB} / \mathrm{c}$ and $\mathrm{C} 57 \mathrm{BL} / 6$ PBMCs were analyzed, and it was determined that the lower limit of sensitivity of the assay for detecting either donor $\left(\mathrm{H} 2-\mathrm{K}^{\mathrm{b}+}\right)$ or host $\left(\mathrm{H} 2-\mathrm{K}^{\mathrm{d}+}\right)$ cells was $0.5 \%$ (22).

Tolerance induction and bone marrow transplantation procedures. Except as noted in specific experiments, bone marrow recipients were treated with our standard protocol for peripheral transplantation tolerance induction $(35,38,43)$. Relative to the transplantation of allogeneic bone marrow on day 0 , mice received a single intravenous DST $\left(1 \times 10^{7}\right.$ spleen cells $)$ on day -7 and four injections of MR1 anti-CD154 mAb $(0.5$ $\mathrm{mg} /$ dose $)$ on days $-7,-4,0$, and $+3(35,38,43)$. The allograft consisted of $50 \times 10^{6}$ or $100 \times 10^{6}$ donor bone marrow cells in a volume of $0.5-1.0 \mathrm{ml}$ injected via the lateral tail vein.

Donor mice were killed in $100 \% \mathrm{CO}_{2}$. For preparation of the DST, spleens were removed, dispersed in sterile medium (RPMI-1640), washed, and counted. Cell viability was assayed by Trypan blue exclusion and was greater than $90 \%$ in all cases. The MR1 hamster anti-mouse CD154 mAb was produced as ascites in scid mice and purified as described previously $(21,43$, 45 ). Bone marrow was obtained by flushing of the femurs and tibiae of donor mice with RPMI using a 24-gauge needle. Recovered cells were filtered through sterile nylon mesh $(70 \mu \mathrm{m}$; Becton Dickinson, Franklin Lakes, New Jersey, USA), counted by hemocytometer, and resuspended in RPMI.

Donor and recipient strain combinations are indicated in the tables. Samples of peripheral venous blood were obtained from recipients at various intervals, and the percentages of donor and host cells were determined by flow microfluorometry. Hematopoietic chimerism was defined as the presence of at least $0.5 \%$ donor-origin PBMCs.

Generation of KB5 TCR transgenic hematopoietic CBA synchimeras. To examine the fate of both developing and mature alloreactive $\mathrm{CD}^{+} \mathrm{T}$ cells in a normal microenvironment, we used KB5 TCR transgenic hematopoietic chimeras (43). The TCR transgene is expressed by $\mathrm{CD}^{+}$cells in CBA $\left(H 2^{k}\right)$ mice and has specificity for $\mathrm{H} 2-\mathrm{K}^{\mathrm{b}}$. The chimeras were generated by injection of small numbers of KB5 transgenic bone marrow cells into sublethally irradiated syngeneic CBA nontransgenic hosts. We refer to these as "synchimeric" mice. In this system, the mice circulate a self-renewing trace population of anti- $\mathrm{H} 2-\mathrm{K}^{\mathrm{b}}$ alloreactive $\mathrm{CD}^{+} \mathrm{T}$ cells that mature in a normal microenvironment (43).

The synchimeras were generated as described previously (43). Briefly, bone marrow cells were collected as described above from male and female KB5 $\times$ $\mathrm{CBA} / \mathrm{JCr} / \mathrm{F}_{1}$ mice $\left(H 2^{k}\right)$. Recipients were male $\mathrm{CBA} / \mathrm{JCr}$ mice 4-7 weeks of age treated with $2 \mathrm{~Gy}$ whole-body $\gamma$-irradiation using a ${ }^{137} \mathrm{Cs}$ source (Gammacell 40; Atomic Energy of Canada Ltd., Ottawa, Ontario, Canada). They were then injected intravenously with $0.5 \times 10^{6}$ transgenic bone marrow cells in a volume of $0.5 \mathrm{ml}$ via the lateral tail vein within 2-5 hours of irradiation. The transgenic $T$ cells that develop express an anti-H2- $\mathrm{K}^{\mathrm{b}}$-specific TCR recognized by the mAb DES (41). These procedures have been documented to generate a stable population of $\mathrm{DES}^{+} \mathrm{CD}^{+}$cells that constitute $5-8 \%$ of PBMCs within 8 weeks of bone marrow transplantation (43).

Skin transplantation. Full-thickness skin grafts about 1 $\mathrm{cm}$ in diameter were obtained from shaved euthanized donors, scraped to remove muscle, and grafted without suturing onto prepared sites on the flanks of anesthetized recipients as described previously (35). Skin grafts were dressed with Vaseline-impregnated gauze and an adhesive bandage for the first week after surgery. Thereafter, skin grafts were assessed 3 times weekly, and rejection was defined as the first day on which the entire graft surface appeared necrotic (35).

Statistical analysis. Parametric data are presented as the arithmetic mean $\pm \mathrm{SD}$. Comparisons of three or more means used one-way ANOVA and the least-significantdifference procedure for a posteriori contrasts (46). Comparisons of two means used unpaired $t$ tests without assuming equal variance (47). In experiments in which large variances were observed, groups were compared nonparametrically with the Mann-Whitney $U$ or the Kruskal-Wallis test (48). Analysis of contingency tables used the $\chi^{2}$ statistic or, in the case of $2 \times 2$ tables, the Fisher exact statistic (48). Skin allograft survival among groups was compared using the method of Kaplan and Meier (49); the equality of allograft-survival distributions for animals in different treatment groups was tested using the log-rank statistic (50). $P$ values less than 0.05 were considered statistically significant. 
Table 1

Hematopoietic chimerism in recipients of $\mathrm{C} 57 \mathrm{BL} / 6$ bone marrow

\begin{tabular}{|c|c|c|c|c|c|c|c|}
\hline Group & Recipient & $\begin{array}{l}\text { Myeloablative } \\
\text { conditioning }\end{array}$ & DST & $\begin{array}{c}\text { Anti-CD154 } \\
\text { mAb }\end{array}$ & $\begin{array}{l}\text { Bone marrow } \\
\text { dose }\left(\times 10^{6}\right)\end{array}$ & $\begin{array}{l}\text { Frequency of } \\
\text { chimerism (\%) }\end{array}$ & $\begin{array}{l}\text { Donor-origin PBMCs } \\
\text { in chimeric mice (\%) }\end{array}$ \\
\hline $\begin{array}{l}1 \\
2 \\
3\end{array}$ & $\begin{array}{c}\mathrm{BALB} / \mathrm{c} \\
\mathrm{CBA} / \mathrm{J} \\
\mathrm{B} 10 . \mathrm{BR}\end{array}$ & $\begin{array}{l}\text { No } \\
\text { No } \\
\text { No }\end{array}$ & $\begin{array}{l}\text { Yes } \\
\text { Yes } \\
\text { Yes }\end{array}$ & $\begin{array}{l}\text { Yes } \\
\text { Yes } \\
\text { Yes }\end{array}$ & $\begin{array}{l}50 \\
50 \\
50\end{array}$ & $\begin{array}{c}17 / 19(89 \%)^{A} \\
17 / 25(68 \%) \\
14 / 14(100 \%)\end{array}$ & $\begin{array}{c}9.2 \pm 3.2 \\
8.3 \pm 4.5 \\
16.9 \pm 12.4^{B}\end{array}$ \\
\hline $\begin{array}{l}4 \\
5 \\
6\end{array}$ & $\begin{array}{l}\mathrm{BALB} / \mathrm{c} \\
\mathrm{CBA} / \mathrm{J} \\
\mathrm{CBA} / \mathrm{J}\end{array}$ & $\begin{array}{l}\text { Yes } \\
\text { Yes } \\
\text { No }\end{array}$ & $\begin{array}{l}\text { Yes } \\
\text { Yes } \\
\text { Yes }\end{array}$ & $\begin{array}{l}\text { Yes } \\
\text { Yes } \\
\text { Yes }\end{array}$ & $\begin{array}{c}50 \\
50 \\
100\end{array}$ & $\begin{array}{l}5 / 5(100 \%) \\
9 / 9(100 \%) \\
5 / 5(100 \%)\end{array}$ & $\begin{array}{l}37.2 \pm 4.3^{\mathrm{C}} \\
35.6 \pm 5.2^{\mathrm{D}} \\
16.5 \pm 5.7^{\mathrm{D}}\end{array}$ \\
\hline $\begin{array}{l}7 \\
8\end{array}$ & $\begin{array}{l}\mathrm{BALB} / \mathrm{c} \\
\mathrm{CBA} / \mathrm{J}\end{array}$ & $\begin{array}{l}\text { No } \\
\text { No }\end{array}$ & $\begin{array}{l}\text { No } \\
\text { No }\end{array}$ & $\begin{array}{l}\text { Yes } \\
\text { Yes }\end{array}$ & $\begin{array}{l}50 \\
50 \\
50\end{array}$ & $\begin{array}{c}0 / 10(0 \%)^{\mathrm{E}} \\
0 / 9(0 \%)^{\mathrm{E}}\end{array}$ & $\begin{array}{l}- \\
-\end{array}$ \\
\hline $\begin{array}{l}9 \\
10\end{array}$ & $\begin{array}{l}\text { B10.BR } \\
\text { B10.BR }\end{array}$ & $\begin{array}{l}\text { No } \\
\text { No }\end{array}$ & $\begin{array}{l}\text { No } \\
\text { No }\end{array}$ & $\begin{array}{l}\text { Yes } \\
\text { No }\end{array}$ & $\begin{array}{l}50 \\
50\end{array}$ & $\begin{array}{c}15 / 15(100 \%) \\
0 / 8(0 \%)^{\mathrm{E}}\end{array}$ & $\begin{array}{c}19.7 \pm 10.9 \\
-\end{array}$ \\
\hline
\end{tabular}

$\mathrm{BALB} / \mathrm{c}\left(H 2^{d}\right), \mathrm{CBA} / \mathrm{J}\left(H 2^{k}\right)$, or B10.BR $\left(H 2^{k}\right)$ mice were randomized to the indicated treatment groups and injected with $\mathrm{C} 57 \mathrm{BL} / 6\left(H 2^{b}\right)$ bone marrow cells on day 0 at the dose indicated. Mice treated with a DST received $10^{7} \mathrm{C} 57 \mathrm{BL} / 6$ spleen cells on day -7 relative to bone marrow transplantation. Mice treated with antiCD154 mAb received four doses of $0.5 \mathrm{mg}$ intraperitoneally on days $-7,-4,0$, and +3 . Hematopoietic chimerism was defined as the presence of at least $0.5 \%$ donororigin ( $\left.\mathrm{H} 2-\mathrm{K}^{\mathrm{b}+}\right)$ PBMCs 6 to 9 weeks after transplantation as described in Methods. ${ }^{\mathrm{A}} P=\mathrm{NS}$ vs. groups 2 and $3 .{ }^{\mathrm{B}} P<0.01$ vs. groups 1 and 2 . ${ }^{\mathrm{C}} P<0.01$ vs. group 1 .

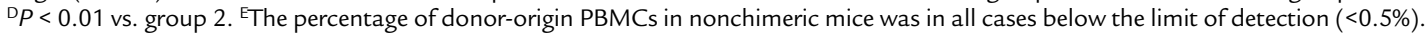

\section{Results}

Induction of peripheral transplantation tolerance facilitates allogeneic stem cell engraftment

Establishment of allogeneic hematopoietic chimerism in the absence of host myeloablative conditioning in BALB/c mice. We first tested our peripheral transplantation tolerance induction protocol for its ability to facilitate the generation of hematopoietic chimerism. BALB/c $\left(H 2^{d}\right)$ mice were treated with a C57BL/6 $\left(H 2^{b}\right)$ DST plus anti-CD154 $\mathrm{mAb}$ and injected with $50 \times 10^{6}$ allogeneic $\mathrm{C} 57 \mathrm{BL} / 6$ bone marrow cells in the absence of myeloablative conditioning. As shown in Table 1 (group 1), $89 \%$ of treated $\mathrm{BALB} / \mathrm{c}$ mice became chimeric. The percentage of donor-origin PBMCs in these mice 8-9 weeks after bone marrow transplantation averaged about $9 \%$. In contrast, in the absence of DST treatment there was no evidence of chimerism in any $\mathrm{BALB} / \mathrm{c}$ mice treated with bone marrow and antiCD154 mAb (Table 1, group 7).

To assess the durability and variability of chimerism, PBMCs were remeasured at intervals 4-30 weeks after transplantation in two independent cohorts of chimeric mice. Chimerism was readily detectable 4 weeks after transplantation and rose to about $10 \%$ (range $6-15 \%$, $n=10$ ) by week 8 (Figure 1). At 30 weeks after transplantation, all mice remained chimeric, and the levels of chimerism were similar to those at week 8 (about $12 \%$, range 2-20\%; Figure 1).

The levels of hematopoietic chimerism achieved generate donor-specific transplantation tolerance in the absence of GVHD. Although we achieved allogeneic hematopoietic chimerism, the levels of chimerism were relatively low. To show that these levels were sufficient to generate transplantation tolerance, subsets of both chimeric and nonchimeric BALB/c mice from the experiments documented in Table 1 (groups 1 and 7 ) were transplanted with C57BL/6 skin allografts 9 weeks after injection of C57BL/ 6 bone marrow. Median survival time (MST) of skin allografts in the chimeric mice was greater than 96 days (Table 2). In contrast, most nonchimeric mice rejected skin allografts rapidly (MST 11 days, $P<0.0005$ ). To document that this state of transplantation tolerance was donor specific, additional chimeric BALB/c mice were transplanted 9 weeks after bone marrow transplantation with third-party skin allografts from $\mathrm{CBA} / \mathrm{J}$ donors. Survival of these four allografts was very brief, all of them rejecting by day 14 (Table 2; $P=$ NS vs. nonchimeric mice).

Animals were observed for signs of GVHD throughout the period of observation (up to 30 weeks). There was no sign of illness in any chimeric bone marrow recipient given the anti-CD154 mAb regimen. Thirty weeks after transplantation, four chimeric BALB/c

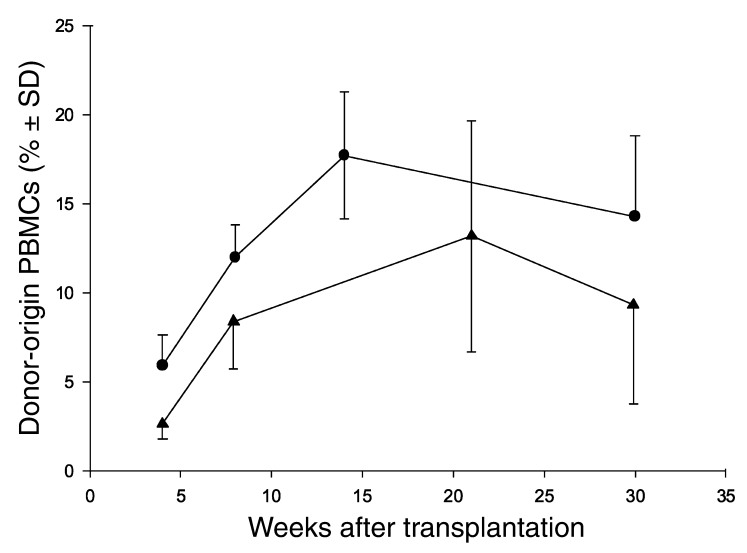

Figure 1

In independent trials, two groups of BALB/c $\left(H 2^{d}\right)$ mice $(n=5$ in each group) were injected with $50 \times 10^{6} \mathrm{C} 57 \mathrm{BL} / 6\left(\mathrm{H}^{6}\right)$ bone marrow cells on day 0 . All mice were treated with a DST consisting of $10^{7} \mathrm{C} 57 \mathrm{BL} / 6$ spleen cells on day -7 relative to bone marrow transplantation. They also received anti-CD154 mAb at a dose of $0.5 \mathrm{mg}$ intraperitoneally on days $-7,-4,0$, and +3 relative to bone marrow transplantation. The percentage of donor-origin PBMCs was measured by flow microfluorometry in all mice 4 weeks, 8 weeks, 14 or 21 weeks, and 30 weeks after bone marrow transplantation as described in Methods. 
Duration of allogeneic skin graft survival

\begin{tabular}{lcccccc}
\hline Host & $\begin{array}{c}\text { DST } \\
\text { donor }\end{array}$ & $\begin{array}{c}\text { Bone marrow } \\
\text { donor }\end{array}$ & Chimeric & $\begin{array}{c}\text { Skin allograft } \\
\text { donor }\end{array}$ & $\begin{array}{c}\text { MST } \\
\text { (days) }\end{array}$ & $\begin{array}{c}\text { Skin allograft } \\
\text { survival (days) }\end{array}$ \\
BALB/c & C57BL/6 & C57BL/6 & Yes & C57BL/6 & $>96$ & $\begin{array}{c}38,>56,80,80,>112, \\
>112,>142,>142^{A}\end{array}$ \\
BALB/c & C57BL/6 & C57BL/6 & Yes & CBA $/ \mathrm{J}$ & 14 & $14,14,14,14$ \\
$\mathrm{BALB} / \mathrm{c}$ & - & $\mathrm{C} 57 \mathrm{BL} / 6$ & No & $\mathrm{C} 57 \mathrm{BL} / 6$ & 11 & $11,11,11,11,49$
\end{tabular}

Randomly selected subsets of both chimeric and nonchimeric BALB/c mice from Table 1 (groups 1 and 7 , respectively) were transplanted with $\mathrm{C} 57 \mathrm{BL} / 6$ or third-party $\mathrm{CBA} / \mathrm{J}$ skin allografts 9 weeks after injection of C57BL/ 6 bone marrow as described in Methods. Mice were observed through day 142 after skin transplantation. MST, median survival time. ${ }^{A} P<0.0005$ vs. other groups.

mice were selected at random and studied histologically. There was no evidence of GVHD in samples of skin, liver, or small or large intestine in any of the mice.

Allogeneic stem cell engraftment using anti-CD154 mAb and DST but no myeloablation can be achieved in $C B A / J$ and $B 10 . B R$ recipient mice. To determine whether the engraftment of allogeneic bone marrow cells in mice treated with DST plus anti-CD154 $\mathrm{mAb}$ is strain dependent, we performed the same experiment using two different strains of mice as recipients. When tested 8-9 weeks after administration of DST, anti-CD154 $\mathrm{mAb}$, and $\mathrm{C} 57 \mathrm{BL} / 6$ bone marrow cells, $68 \%$ of $\mathrm{CBA} / \mathrm{J}$ mice (Table 1, group 2) and $100 \%$ of B10.BR mice (group 3 ) had become chimeric. In both cases, the frequency of chimerism was statistically similar to that achieved using $\mathrm{BALB} / \mathrm{c}$ recipients (group $1, P=\mathrm{NS}$ ). The percentage of donor-origin PBMCs in chimeric $\mathrm{CBA} / \mathrm{J}$ mice $(\sim 8 \%)$ was similar to that in chimeric $\mathrm{BALB} / \mathrm{c}$ mice $(P=\mathrm{NS})$, but levels in both $\mathrm{BALB} / \mathrm{c}$ and CBA recipients were significantly less $(P<0.01)$ than levels achieved in B10.BR mice ( 17\%).

Like BALB/c mice, CBA/J recipients of bone marrow and anti-CD154 mAb but no DST did not become chimeric (Table 1, group 8). In contrast, B10.BR mice treated in the same way uniformly became chimeric (group 9). As was true for B10.BR recipients given both anti-CD154 $\mathrm{mAb}$ and a DST (group 3), about $20 \%$ of their PBMCs were of donor origin. In both groups of B10.BR chimeras, the percentage of donor-origin cells was quite variable, ranging from $2.6 \%$ to $46.0 \%$. B10.BR mice treated with a bone marrow graft but neither anti-CD154 mAb nor DST failed to become chimeric (group 10).

Increasing bone marrow cell dose or adding minimal myeloablative conditioning increases levels of chimerism. Because hematopoietic chimerism can be established in the absence of myeloablative conditioning if very large numbers of bone marrow cells are transplanted $(27,29)$, we studied the effect of increasing the donor inoculum in mice treated with both DST and anti$\mathrm{CD} 154 \mathrm{mAb}$. Transplantation of $100 \times 10^{6} \mathrm{C} 57 \mathrm{BL} / 6$ bone marrow cells into $\mathrm{CBA} / \mathrm{J}$ recipients was associated with uniform generation of chimerism (Table 1, group 6), and the percentage of donor-origin PBMCs in these mice was, on average, double that observed in $\mathrm{CBA} / \mathrm{J}$ recipients of $50 \times 10^{6}$ C57BL/ 6 cells (Table 1 , group 2, $P=0.025$ ).

The addition of minimal myeloablation also appeared to improve outcome. Both BALB/c (Table 1, group 4) and CBA/J (group 5) recipients uniformly became chimeric if treated with 1 Gy of whole-body irradiation prior to DST, anti-CD154 mAb, and infusion of $50 \times 10^{6}$ C57BL/ 6 bone marrow cells. In both cases, donor-origin cells constituted more than a third of the PBMC population 6-7 weeks after bone marrow injection, and these percentages were statistically significantly greater than the percentages achieved without conditioning (Table 1 , groups 1 and $2, P<0.001$ for both comparisons).

Timing of DST and anti-CD154 mAb treatment is important for generation of allogeneic chimerism

In studies of induction of solid organ transplantation tolerance, we have shown that administration of DST plus anti-CD154 mAb leads to the deletion of peripheral host alloreactive $\mathrm{CD}^{+} \mathrm{T}$ cells, an effect that is maximal approximately 3 days after the initiation of treatment (38). We hypothesized that deletion of host alloreactive $\mathrm{CD}^{+} \mathrm{T}$ cells would define the optimal time point at which allogeneic bone marrow chimerism could be achieved in the absence of myeloablative conditioning. We tested this hypothesis by varying the timing of DST plus anti-CD154 mAb treatment in relation to $\mathrm{C} 57 \mathrm{BL} / 6$ bone marrow transplantation into $\mathrm{CBA} / \mathrm{J}$ recipients. In these experiments, the first of the four injections of anti-CD154 mAb was always given immediately before the DST.

When DST was given 10 or 14 days before bone marrow transplantation, $60 \%$ and $80 \%$ of recipients, respectively, became chimeric (Table 3 , groups 1 and 2);

\section{Table 3}

Hematopoietic chimerism in CBA/J recipients of C57BL/ 6 bone marrow

$\begin{array}{cccc}\text { Group } & \begin{array}{c}\text { Day of DST } \\ \text { injection }\end{array} & \begin{array}{c}\text { Frequency of } \\ \text { chimerism (\%) }\end{array} & \begin{array}{c}\text { Donor-origin PBMCs } \\ \text { in chimeric mice (\%) }\end{array} \\ 1 & -14 & 4 / 5(80 \%)^{\mathrm{A}} & 10.2 \pm 1.9 \\ 2 & -10 & 3 / 5(60 \%)^{\mathrm{A}} & 10.4 \pm 4.2 \\ 3 & -5 & 0 / 5(0 \%)^{\mathrm{B}} & - \\ 4 & -3 & 0 / 5(0 \%)^{\mathrm{B}} & -\end{array}$

Groups of CBA $/ \mathrm{J}\left(H 2^{k}\right)$ mice were randomized and transplanted with $50 \times 10^{6}$ $\mathrm{C} 57 \mathrm{BL} / 6\left(\mathrm{H} 2^{b}\right)$ bone marrow cells on day 0 . All mice also received a single C57BL/ 6 DST consisting of $10^{7}$ spleen cells on day $-3,-5,-10$, or -14 relative to bone marrow transplantation. In addition, all mice were injected intraperitoneally with four doses of $0.5 \mathrm{mg}$ anti-CD154 mAb on days $0,+3$, +7 , and +10 relative to the DST. The temporal relationship of the DST and anti-CD154 mAb injections was the same as in Table 1; only the timing of the bone marrow graft was varied. No myeloablative conditioning was performed. Chimerism was defined as the presence of at least $0.5 \%$ donor-origin $\left(\mathrm{H} 2-\mathrm{K}^{\mathrm{b}+}\right)$ PBMCs 6 weeks after transplantation. ${ }^{A} P=\mathrm{NS}$ vs. Table 1 , group 2. ${ }^{\mathrm{B}} P<0.01$ vs. Table 1 , group 2 . 
this rate of success was comparable to that achieved when DST was injected 7 days before transplantation (68\%; Table 1, group 2, $\chi^{2}=0.44, P=\mathrm{NS}$ ). The percentage of donor-origin PBMCs detected 6 or more weeks after transplantation in the mice that became chimeric was approximately $10 \%$, irrespective of the timing of the DST.

In contrast, when DST was injected 5 or 3 days before bone marrow transplantation, no recipients became chimeric (Table 3 , groups 3 and $4, \chi^{2}=13.22$, $P<0.02$ vs. Table 1 , group 2$)$. Given that host alloreactive $\mathrm{CD}^{+} \mathrm{T}$ cells are deleted in mice treated with DST plus anti-CD154 mAb at these time points (38), the result was unexpected.

The combination of DST, anti-CD154 mAb, and bone marrow engraftment leads to permanent deletion of host alloreactive $\mathrm{CD8}^{+}$peripheral $\mathrm{T}$ cells

In studies of peripheral-tolerance induction using DST plus anti-CD154 mAb, we have documented that host alloreactive $\mathrm{CD}^{+} \mathrm{T}$ cells are deleted, that these cells then reappear over time, and that their reappearance is associated with rejection of healed-in allografts (43). Given the apparent permanence of hematopoietic chimerism in mice treated with DST, anti-CD154 $\mathrm{mAb}$, and bone marrow, we hypothesized that establishment of chimerism would lead to permanent deletion of peripheral alloreactive $\mathrm{CD}^{+} \mathrm{T}$ cells. To test this hypothesis, we used KB5 synchimeric mice. These mice circulate small numbers of $\mathrm{TCR}$ transgenic alloreactive $\mathrm{CD} 8^{+} \mathrm{T}$ cells that are continuously replenished over time as newly generated KB5 T cells are released from the thymus (43).

KB5 synchimeric mice were randomized into four groups. Mice in group 1 (Figure 2) were untreated. Mice in groups 2 and 3 received anti-CD $154 \mathrm{mAb}$ plus either a C57BL/6 spleen cell DST (group 2) or C57BL/ 6 bone marrow (group 3). Mice in group 4 received anti-CD154 mAb plus a C57BL/ 6 spleen cell DST and C57BL/ 6 bone marrow.

The level of alloreactive $\mathrm{DES}^{+} \mathrm{CD}^{+} \mathrm{T}$ cells in the peripheral blood of these four groups of mice is shown in Figure 2. The level of $\mathrm{DES}^{+} \mathrm{CD}^{+} \mathrm{T}$ cells in control mice during the period of observation was approximately 5-6.5\%; these levels are comparable to those we have reported previously in this model system (43).

None of the mice in groups 2 and 3 became chimeric; no donor-origin cells were detectable at any time point throughout the 15 -week period of observation. As expected, and consistent with previous reports (43), the level of alloreactive $\mathrm{DES}^{+} \mathrm{CD}^{+} \mathrm{T}$ cells in mice treated with anti-CD154 $\mathrm{mAb}$ and a C57BL/6 splenocyte transfusion (group 3 ) was much lower within 2 weeks of transfusion $(\sim 0.8 \%)$. Thereafter the levels rose slowly and recovered to about $2.4 \%$ by week 15 . The behavior of mice treated with anti-CD154 mAb and bone marrow (group 2) was similar, although the initial decline was less dramatic than that associated with the use of a splenocyte transfusion alone.
The results for the mice treated with anti-CD154 $\mathrm{mAb}$, a splenocyte DST, and then a bone marrow allograft (group 4) were much different. As expected, six of eight $(75 \%)$ became chimeric. The percentage of donororigin PBMCs 9 weeks after transplantation was high $(22.3 \% \pm 13.2 \%)$ and remained at about this level throughout the 15 -week period of observation. In striking contrast to the outcome in the other groups, the level of $\mathrm{DES}^{+} \mathrm{CD}^{+} \mathrm{T}$ cells in the six chimeric mice fell within 2 weeks to below the limit of detection and remained that low throughout the period of observation ( $P \leq 0.001$ vs. all other groups at week 15$)$.

\section{Intrathymic deletion of alloreactive $\mathrm{DES}^{+} \mathrm{CD}^{+} \mathrm{CD}^{-}$} $\mathrm{T}$ cells in allogeneic hematopoietic chimeras

Normal distribution of $C D 4$ and $C D 8$ cells in the thymus of KB5 synchimeric mice. The long-term absence of peripheral alloreactive $\mathrm{DES}^{+} \mathrm{CD}^{+}$cells in mice with hematopoietic chimerism suggested that they might be

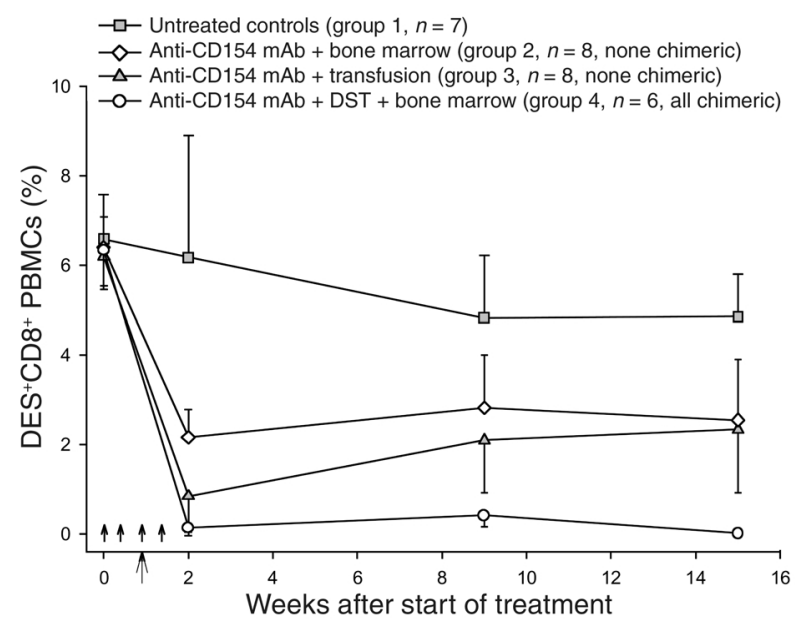

Figure 2

Deletion of peripheral host alloreactive $\mathrm{CD}^{+} \mathrm{T}$ cells. KB5 CBA synchimeras were randomized into four cohorts. Group 1 was untreated. Group 2 was injected with four doses of anti-CD154 $\mathrm{mAb}$ on days $0,+3,+7$, and +10 (short arrows), and with $50 \times 10^{6}$ $\mathrm{C} 57 \mathrm{BL} / 6$ bone marrow cells on day +7 (long arrow). Group 3 received four doses of $0.5 \mathrm{mg}$ of anti-CD154 mAb at the same intervals (short arrows) plus a transfusion of C57BL/ 6 spleen cells on day 0 . Group 4 received a DST of C57BL/ 6 spleen cells on day 0 and anti-CD154 mAb on days $0,+3,+7$, and +10 , in addition to an injection of $50 \times 10^{6} \mathrm{C} 57 \mathrm{BL} / 6$ bone marrow cells on day +7 . The percentage of $\mathrm{DES}^{+} \mathrm{CD} 8^{+}$cells in the blood was determined on day 0 (before any treatment) and then at the indicated times. Within 2 weeks of treatment, the percentage of $\mathrm{DES}^{+} \mathrm{CD} 8^{+}$peripheral blood cells was significantly lower in all treatment groups compared with controls $(P<0.001)$. Thereafter, the percentage of $\mathrm{DES}^{+} \mathrm{CD} 8^{+}$ peripheral blood cells in groups 2 and 3 tended to rise toward that observed in controls, but even at week 15 the percentage remained less than in controls $(P<0.001)$. In contrast, the percentage of $\mathrm{DES}^{+} \mathrm{CD}^{+}$peripheral blood cells in group 4 remained extremely low throughout the course of the experiment and, at week 15, was significantly lower than in all other groups $(P \leq 0.001$ for each comparison). With respect to chimerism, defined as at least $0.5 \%$ donororigin $\left(\mathrm{H} 2-\mathrm{K}^{\mathrm{b}+}\right)$ PBMCs 9 weeks after transplantation, all mice in group 4 were chimeric and none in groups 2 or 3 was chimeric. 
Table 4

Hematopoietic chimerism and host alloreactive $\mathrm{CD} 8{ }^{+} \mathrm{T}$ cells in $\mathrm{KB} 5$ synchimeric recipients of $\mathrm{C} 57 \mathrm{BL} / 6$ bone marrow

\begin{tabular}{|c|c|c|c|c|c|c|}
\hline Group & $\begin{array}{l}\text { Transfusion } \\
\text { donor }\end{array}$ & $\begin{array}{l}\text { Bone marrow } \\
\text { donor }\end{array}$ & $n$ & Chimeric & $\begin{array}{l}\text { Time of analysis relative to } \\
\text { completion of treatment }\end{array}$ & $\begin{array}{l}\text { Host } \mathrm{CD}^{+} \mathrm{CD} 4^{-} \text {thymocytes } \\
\text { that were } \mathrm{DES}^{+}(\%)\end{array}$ \\
\hline 1 & None & None & 11 & - & $\begin{array}{c}\text { Same approximate age as groups } 2-8 \\
\text { No treatment given }\end{array}$ & $26.4 \pm 20.8^{\mathrm{B}}$ \\
\hline 2 & C57BL/ 6 & None & 3 & - & $-3 d$ & $18.6 \pm 4.8$ \\
\hline 3 & $\mathrm{C} 57 \mathrm{BL} / 6$ & None & 7 & - & $0 d$ & $25.7 \pm 11.2$ \\
\hline 4 & $\mathrm{C} 57 \mathrm{BL} / 6$ & None & 4 & - & $+15 d$ & $38.2 \pm 21.7$ \\
\hline 5 & $\mathrm{C} 57 \mathrm{BL} / 6$ & $\mathrm{C} 57 \mathrm{BL} / 6$ & 4 & $?^{A}$ & $+15 d$ & $16.2 \pm 13.8^{\mathrm{C}}$ \\
\hline 6 & C57BL/6 & None & 6 & No & +21 to $+30 d$ & $30.4 \pm 13.9$ \\
\hline 7 & $\mathrm{C} 57 \mathrm{BL} / 6$ & $\mathrm{C} 57 \mathrm{BL} / 6$ & 3 & No & +21 to $+30 d$ & $30.4 \pm 8.9$ \\
\hline 8 & $\mathrm{C} 57 \mathrm{BL} / 6$ & $\mathrm{C} 57 \mathrm{BL} / 6$ & 3 & Yes & +21 to $+30 d$ & All $<0.2^{\mathrm{D}}$ \\
\hline 9 & None & None & 3 & - & Age matched, never treated & $2.8 \pm 0.6$ \\
\hline 10 & $\mathrm{C} 57 \mathrm{BL} / 6$ & C57BL/6 & 2 & No & 35 weeks & $4.4,18.3$ \\
\hline 11 & C57BL/ 6 & C57BL/6 & 3 & Yes & 35 weeks & All $<0.2^{\mathrm{E}}$ \\
\hline
\end{tabular}

$\mathrm{CBA} / \mathrm{J}\left(\mathrm{H} 2^{k}\right)$ mice approximately 4 weeks of age were irradiated (2 Gy) and injected with bone marrow from KB5 CBA/J TCR transgenic donors as described in Methods. Eight to ten weeks later, with no additional irradiation, these KB5 CBA/J synchimeras received a DST consisting of $10^{7} \mathrm{C} 57 \mathrm{BL} / 6\left(\mathrm{H} 2^{b}\right)$ spleen cells on day -7 plus four intraperitoneal doses of anti-CD154 mAb $(0.5 \mathrm{mg} /$ dose $)$ on days $-7,-4,0,+3$ relative to intravenous injection of $50 \times 10^{6} \mathrm{C} 57 \mathrm{BL} / 6$ bone marrow cells on day 0 . Thymi were recovered at the indicated time points relative to marrow transplantation on day 0 , and the percentage of host anti-donor alloreactive $\mathrm{DES}{ }^{+} \mathrm{CD} 88^{+} \mathrm{CD} 4-$ thymocytes was measured by flow microfluorometry. ${ }^{A} \mathrm{At}$ the 15 -day time point, it cannot reliably be determined whether mice are chimeric. ${ }^{B} P=N S$ vs. groups 2 and 3 . ${ }^{C} P=0.08$ vs. group 4 . $D P<0.01$ vs. groups 6 and 7 . ${ }^{E} P<0.05$ vs. combined groups 9 and 10 .

undergoing intrathymic deletion. Before proceeding to test this possibility, we first analyzed overall thymic maturation in the untreated KB5 synchimeric mouse. It was important to do so because the KB5 transgenic mice used to generate synchimeras have an abnormally large population of single-positive $\mathrm{CD}^{+}$cells in the thymus (51). We observed, however, that KB5 synchimeric mice exhibit a normal distribution of total $\mathrm{CD}^{+}$and $\mathrm{CD}^{+}$thymocytes (52-54). The thymocytes of untreated KB5 synchimeric mice consisted of a large population of double-positive cells $(81.5 \% \pm 4.3 \%, n=14)$ and smaller populations of CD $4{ }^{+} \mathrm{CD}^{-}$single-positive cells $(9.4 \% \pm 1.4 \%, n=14)$ and $\mathrm{CD} 4-\mathrm{CD}^{+}$single-positive cells $(4.4 \% \pm 1.6 \%, n=14)$. Representative histograms are shown in Figure 3. These percentages of single- and double-positive thymocytes are typical of those observed in normal untreated adult mice (52-54).

$D E S^{+} C D 8^{+} C D 4^{-}$thymocytes are not deleted by treatment with DST plus anti-CD154 mAb. Having determined that the overall distribution of thymocyte $\mathrm{CD}^{+}$and $\mathrm{CD}^{+}$

\section{Figure 3}

Intrathymic deletion of host alloreactive $\mathrm{DES}^{+} \mathrm{CD} 8^{+} \mathrm{CD} 4^{-}$thymocytes. KB5 CBA synchimeras were randomized into two groups. Group 1 (upper panels) was left untreated. Group 2 (lower panels) was injected with a C57BL/ 6 DST on day -7 and anti-CD154 mAb on days $-7,-4,0$, and +3 relative to injection of $50 \times 10^{6} \mathrm{C} 57 \mathrm{BL} / 6$ bone marrow cells on day 0 . Thymi were recovered 35 weeks after bone marrow transplantation and analyzed by flow microfluorometry for the percentage of DES ${ }^{+} \mathrm{CD} 8^{+} \mathrm{CD} 4-$ thymocytes as described in Methods. Shown in the left column are representative dot plots; the percentage of cells expressing CD4 and CD8 is indicated in each quadrant. The right column presents histograms; the horizontal bars depict the gates used to determine the number of DES ${ }^{+}$cells in the $C D 8^{+} \mathrm{CD} 4^{-}$quadrant. Representative data are shown; the complete data set is given in Table 4. phenotypes in synchimeric mice is normal, we next measured the percentages of $\mathrm{DES}^{+} \mathrm{CD}^{+}$thymocytes following costimulation blockade and splenocyte transfusion. Before any treatment, the percentage of $\mathrm{CD}^{+} \mathrm{CD} 4$ thymocytes that were also $\mathrm{DES}^{+}$was $26.4 \% \pm 20.8 \%$ (Table 4, group 1). $\mathrm{DES}^{+} \mathrm{CD}^{+} \mathrm{CD}^{-}$thymocytes were also readily detectable at statistically similar levels 4 and 7 days after treatment with DST and anti-CD154 mAb (Table 4, groups 2 and 3, $P=\mathrm{NS}$ ). In contrast, it is known that peripheral $\mathrm{DES}^{+} \mathrm{CD}^{+}$cells are deleted within 3 days of treatment with DST plus anti-CD154 mAb, well before graft placement (38).
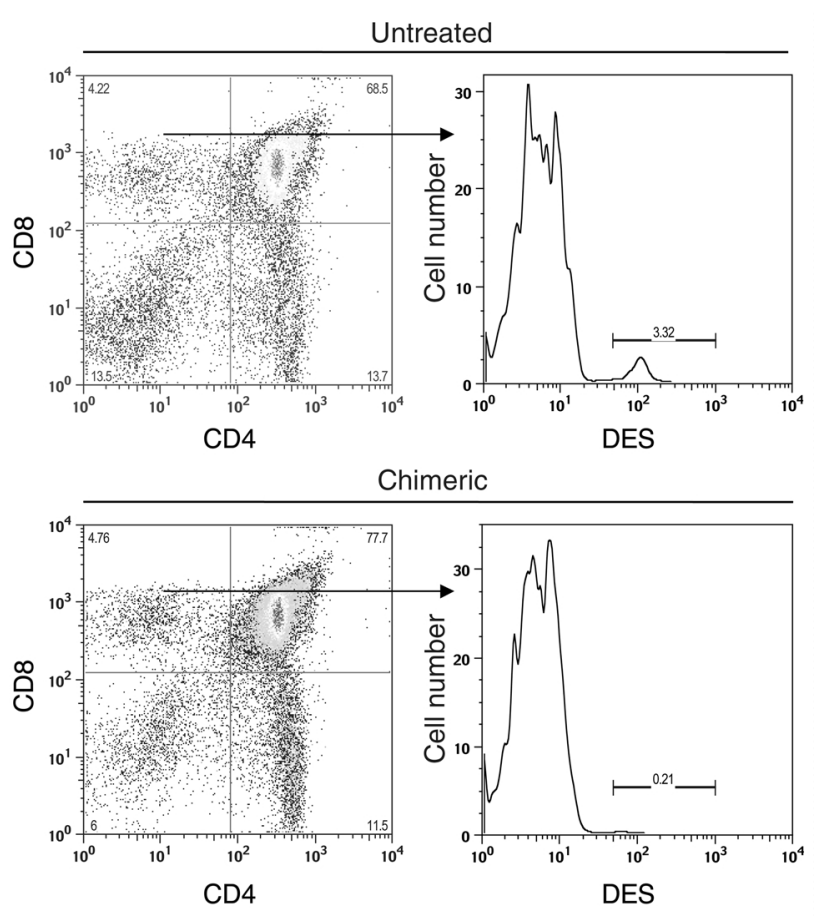
Bone marrow cell engraftment in mice treated with DST plus anti-CD154 mAb leads to intrathymic deletion of $D E S^{+} C D 8^{+} C D 4^{-}$cells. We next tested the hypothesis that successful generation of hematopoietic chimerism subsequent to treatment with DST and anti-CD154 $\mathrm{mAb}$ would lead to the deletion of $\mathrm{DES}^{+} \mathrm{CD}^{+} \mathrm{CD} 4^{-}$ alloreactive thymocytes. As shown in Table 4, 15 days after bone marrow transplantation the percentage of $\mathrm{DES}^{+} \mathrm{CD}^{+} \mathrm{CD}^{-}$- thymocytes in mice treated with DST and anti-CD154 mAb (Table 4, group 5) was about $50 \%$ less than in age-matched mice that had been given DST and anti-CD154 mAb but no graft (group 4), but at this time point the difference was not statistically significant $(P=0.08)$. By $21-30$ days after bone marrow injection, it was possible to distinguish chimeric and nonchimeric recipients. At this time point, levels of $\mathrm{DES}^{+} \mathrm{CD}^{+} \mathrm{CD}^{-}$thymocytes remained at high baseline levels in both mice that had received DST plus anti-CD154 mAb but no graft (Table 4, group 6) and mice that had received DST plus anti-CD154 mAb plus a graft but had not become chimeric (group 7). In contrast, $\mathrm{DES}^{+} \mathrm{CD}^{+} \mathrm{CD}^{-}$thymocytes were undetectable $(<0.3 \%)$ in all chimeric mice (group $8, P<0.01$ vs. both group 6 and group 7).

Additional mice were studied 35 weeks after treatment to assess the durability of alloreactive-thymocyte deletion. We first noted that the percentage of $\mathrm{DES}^{+} \mathrm{CD} 8^{+} \mathrm{CD} 4^{-}$thymocytes in age-matched but untreated synchimeras had spontaneously fallen over time, but that such thymocytes were nonetheless readily detectable. The decline was from about $26 \%$ at base line (Table 4, group 1) to about 3\% 8-9 months later (Table 4, group 9, $P=0.01$ ). $\mathrm{DES}^{+} \mathrm{CD}^{+} \mathrm{CD}^{-}$thymocytes were also readily detectable in two recipients of DST, anti-CD154 mAb, and bone marrow that had not become chimeric (group 10). In contrast, no $\mathrm{DES}^{+} \mathrm{CD} 8^{+} \mathrm{CD} 4^{-}$thymocytes could be detected in any of three recipients of DST, anti-CD154 mAb, and bone marrow that had become and remained chimeric (Table 4 , group $11, P<0.05)$. A representative histogram documenting the disappearance of $\mathrm{DES}^{+} \mathrm{CD} 8^{+} \mathrm{CD} 4^{-}$thymocytes in one of the chimeric mice from group 11 is shown in Figure 3. Although lacking in $\mathrm{DES}^{+} \mathrm{CD}^{+} \mathrm{CD} 4{ }^{-}$ thymocytes, the thymi of these mice 35 weeks after bone marrow transplantation were clearly allochimeric. The presence of both host $\left(\mathrm{H} 2-\mathrm{K}^{\mathrm{k}}\right)$ and donor $\left(\mathrm{H} 2-\mathrm{K}^{\mathrm{b}}\right)$ thymocytes was confirmed by flow microfluorometry (data not shown).

Allospecific and non-allospecific mechanisms are important for engraftment of bone marrow cells

MHC-matching of the DST and bone marrow donors is not required for allogeneic bone marrow engraftment in normal mice. Induction of peripheral transplantation tolerance using DST and anti-CD154 $\mathrm{mAb}$ requires that the MHC of the transfusion donor be the same as that of the graft donor (i.e., "donor specific") (35). We hypothesized that successful generation of hematopoietic chimerism using our protocol would also require MHC-matching of the transfusion and bone marrow cells, i.e., that the transfusion had to be donor specific. To test this hypothesis, CBA mice $\left(H 2^{k}\right)$ were treated with a C57BL/6 $\left(H 2^{b}\right)$ non-donor-specific spleen cell transfusion plus anti-CD154 $\mathrm{mAb}$ and then injected with $\mathrm{BALB} / \mathrm{c}\left(H 2^{d}\right)$ bone marrow cells. Unexpectedly, all became chimeric (Table 5 , group 1 ). To verify this outcome, we reversed the DST and bone marrow donors. CBA mice $\left(H 2^{k}\right)$ were treated with $\mathrm{BALB} / \mathrm{c}\left(H 2^{d}\right)$ spleen cell transfusion plus anti-CD154 $\mathrm{mAb}$ and then injected with C57BL/6 $\left(H 2^{b}\right)$ bone marrow cells. Again, the majority $(90 \%)$ of these mice became chimeric (Table 5, group 2).

Reduction of high numbers of host alloreactive $C D 8^{+} T$ cells is required for bone marrow engraftment in KB5 synchimeras. To begin to determine the role of the spleen cell transfusion in facilitating subsequent engraftment of bone marrow cells, we used KB5 synchimeras. In addition to circulating their normal complement of alloreactive $\mathrm{T}$ cells, these mice also circulate large numbers $(6-8 \%)$ of $\mathrm{DES}^{+} \mathrm{CD}^{+}$alloreactive (anti-H2- $\mathrm{K}^{\mathrm{b}}$ ) T cells (38). Using our standard protocol, which is known to delete $\mathrm{DES}^{+} \mathrm{CD}^{+}{ }^{+}$peripheral $\mathrm{T}$ cells (38), we observed that two of three KB5 synchimeras given a C57BL/6 DST, anti$\mathrm{CD} 154 \mathrm{mAb}$, and C57BL/ 6 bone marrow cells became chimeric (Table 5, group 3). Confirming the results obtained in normal CBA/J mice (Table 5, group 1), all KB5 synchimeras treated with $\mathrm{C} 57 \mathrm{BL} / 6$ spleen cell transfusion plus anti-CD154 mAb and then given

Table 5

Frequency of chimerism in $\mathrm{CBA} / \mathrm{J}$ and $\mathrm{KB} 5 \mathrm{CBA} / \mathrm{J}$ bone marrow recipients

\begin{tabular}{lccccc} 
Group & Host & $\begin{array}{c}\text { Transfusion } \\
\text { donor }\end{array}$ & $\begin{array}{c}\text { Bone marrow } \\
\text { donor }\end{array}$ & $\begin{array}{c}\text { Frequency of } \\
\text { chimerism (\%) }\end{array}$ & $\begin{array}{c}\text { Donor-origin PBMCs } \\
\text { in chimeric mice (\%) }\end{array}$ \\
1 & $\mathrm{CBA} / \mathrm{J}$ & $\mathrm{C} 5 \mathrm{BL} / 6$ & $\mathrm{BALB} / \mathrm{c}$ & $9 / 9(100 \%)$ & $2.8 \pm 0.8$ \\
2 & $\mathrm{CBA} / \mathrm{J}$ & $\mathrm{BALB} / \mathrm{c}$ & $\mathrm{C} 57 \mathrm{BL} / 6$ & $9 / 10(90 \%)$ & $7.4 \pm 2.1$ \\
3 & $\mathrm{CB} / 6 \mathrm{BL} / 6$ & $\mathrm{BALB} / \mathrm{c}$ & $5 / 3(67 \%)$ & $22.1 \pm 10.4$ \\
4 & $\mathrm{~KB} 5 \mathrm{CBA} / \mathrm{J}$ Synchimera & $\mathrm{C} 57 \mathrm{BL} / 6$ & $\mathrm{C} 57 \mathrm{BL} / 6$ & $0 / 4(0 \%)^{\mathrm{A}}$ & $27.1 \pm 5.9$ \\
5 & $\mathrm{~KB} 5 \mathrm{CBA} / \mathrm{J}$ Synchimera & $\mathrm{BALB} / \mathrm{c}$ & & $<0.5$ \\
\hline
\end{tabular}

$\mathrm{CBA} / \mathrm{J}\left(H 2^{k}\right)$ and KB5 CBA/J TCR transgenic synchimeric mice $\left(H 2^{k}\right)$ were injected intravenously with $10^{7}$ spleen cells on day -7 and intraperitoneally with four doses of $0.5 \mathrm{mg}$ anti-CD154 mAb on days $-7,-4,0$, and +3 relative to intravenous injection of $50 \times 10^{6}$ bone marrow cells on day 0 . Transfusion and bone marrow donors were either C57BL/6 $\left(H 2^{b}\right)$ or BALB/c $\left(H 2^{d}\right)$ as indicated. No myeloablative conditioning was used. The percentage of donororigin PBMCs was measured 8-9 weeks after bone marrow transplantation by flow microfluorometry. Chimerism was defined as the presence of at least $0.5 \%$ PBMCs of donor origin. ${ }^{A} P<0.01$ vs. group 4 . 
Table 6

Frequency of chimerism in $\mathrm{BALB} / \mathrm{c}$ recipients of $\mathrm{C} 57 \mathrm{BL} / 6$ bone marrow

$\begin{array}{lcccccc}\text { Group } & \text { Host } & \text { DST donor } & \text { Bone marrow donor } & \text { Recipient treatment } & \begin{array}{c}\text { Frequency of } \\ \text { chimerism (\%) }\end{array} & \begin{array}{c}\text { Donor-origin PBMCs } \\ \text { in chimeric mice (\%) }\end{array} \\ 1 & \mathrm{BALB} / \mathrm{c} & \text { None } & \mathrm{C} 57 \mathrm{BL} / 6 & \text { Anti-CD } 6 \mathrm{mAb} & 2 / 9(22 \%)^{\mathrm{A}} & 6.3,4.8 \\ 2 & \mathrm{BALB} / \mathrm{c} & \text { None } & \mathrm{C} 57 \mathrm{BL} / 6 & \text { Anti-CD122 mAb } & 9 / 9(100 \%)^{\mathrm{B}} & 6.8 \pm 2.4 \\ 3 & \mathrm{BALB} / \mathrm{c} & \mathrm{C} 57 \mathrm{BL} / 6 & \mathrm{C} 57 \mathrm{BL} / 6 & \text { Anti-CTLA4 mAb } & 2 / 9(22 \%)^{\mathrm{C}} & 5.5,2.0 \\ 4 & \mathrm{BALB} / \mathrm{c} & \mathrm{C} 57 \mathrm{BL} / 6 & \mathrm{C} 57 \mathrm{BL} / 6 & \text { Anti-CD4 mAb } & 6 / 9(67 \%)^{\mathrm{B}} & 2.7 \pm 1.2^{\mathrm{B}} \\ 5 & \mathrm{BALB} / \mathrm{c} & \mathrm{C} 57 \mathrm{BL} / 6 & \mathrm{C} 57 \mathrm{BL} / 6 & \text { Anti-CD25 mAb } & 8 / 9(89 \%)^{\mathrm{B}} & 6.0 \pm 1.6\end{array}$

$\mathrm{BALB} / \mathrm{c}$ mice were randomized and injected with $50 \times 10^{6} \mathrm{C} 57 \mathrm{BL} / 6$ bone marrow cells on day 0 . All mice were injected intraperitoneally with four doses of 0.5 $\mathrm{mg}$ anti-CD154 mAb on days $-7,-4,0$, and +3 relative to bone marrow transplantation. In the groups indicated, anti-CD8 (0.5 mg/dose), anti-CD4 (0.5 $\mathrm{mg} /$ dose), or anti-CTLA4 ( $0.075 \mathrm{mg} /$ dose) mAb was injected intraperitoneally on days $-7,-6$, and -5 relative to bone marrow transplantation. Anti-CD122 $\mathrm{mAb}(1 \mathrm{mg} /$ dose) was injected intraperitoneally on days -8 and -1 relative to bone marrow transplantation. Anti-CD25 $\mathrm{mAb}(0.25 \mathrm{mg} / \mathrm{dose})$ was injected intraperitoneally on day -1 . Mice in groups 3,4 , and 5 received a single donor-specific transfusion consisting of $10^{7} \mathrm{C} 57 \mathrm{BL} / 6$ spleen cells on day -7 relative to bone marrow cell transplantation. ${ }^{A} P<0.005$ vs. group 2 and Table 1 , group $1 .{ }^{B} P=$ NS vs. Table 1 , group 1 . $C P<0.001$ vs. Table 1 , group 1.

$\mathrm{BALB} / \mathrm{c}\left(H 2^{d}\right)$ bone marrow became chimeric (Table 5, group 4). We then reversed the MHCs of the transfusion and bone marrow donors and found, in contrast, that no KB5 synchimeric mice became allochimeric when treated with $\mathrm{BALB} / \mathrm{c}$ spleen cell transfusion plus anti$\mathrm{CD} 154 \mathrm{mAb}$ and then given C57BL/6 $\left(H 2^{b}\right)$ bone marrow cells (Table 5 , group $5, P<0.01$ vs. group 4 ). The result suggests that, in the presence of large numbers of allospecific $T$ cells in the recipient, as in the synchimera with large numbers of anti-H2- $\mathrm{K}^{\mathrm{b}} \mathrm{T}$ cells, the transfusion may need to be matched to that allospecificity.

Host $\mathrm{CD}^{+}$cell deletion is not sufficient for optimal engraftment of allogeneic bone marrow cells

We have previously shown that, in part, the role of DST in our costimulation blockade protocol for peripheraltolerance induction is to enhance the deletion of host alloreactive $\mathrm{CD}^{+} \mathrm{T}$ cells $(38,43)$. The phenotyping analyses of KB5 synchimeras in which hematopoietic chimerism was successfully generated suggest that deletion of both peripheral host alloreactive $\mathrm{CD}^{+} \mathrm{T}$ cells and host alloreactive thymocytes is required. We next tested the hypothesis that host $\mathrm{CD}^{+} \mathrm{T}$ cell deletion is required but not sufficient for establishing hematopoietic chimerism; we did so by replacing the DST in our protocol with a depleting anti-CD8 $\mathrm{mAb}$. We observed that the frequency of chimerism in $\mathrm{BALB} / \mathrm{c}$ recipients treated with anti-CD8 $\mathrm{mAb}$ and anti-CD154 mAb before transplantation of C57BL/6 bone marrow was much lower (22\%; Table 6, group 1) than in recipients treated with anti-CD154 mAb and DST (Table 1 , group $1, P<0.001$ ). The result suggests that the role of DST in facilitating engraftment of allogeneic bone marrow cells involves mechanisms in addition to the deletion of host alloreactive $\mathrm{CD}^{+} \mathrm{T}$ cells.

Combined treatment with anti-CD154 $\mathrm{mAb}$ and anti-CD122 $\mathrm{mAb}$ leads to hematopoietic chimerism in $\mathrm{BALB} / \mathrm{c}$ recipients of $\mathrm{C} 57 \mathrm{BL} / 6$ bone marrow

NK cells, which are $\mathrm{CD} 122^{+}$, are known to be important in the rejection of allogeneic bone marrow (55-58). CD122 is expressed on most NK cells and activated macrophages, and on a subset of activated $\mathrm{CD}^{+} \mathrm{T}$ cells, and anti-CD122 mAb has been shown to delete NK cell activity in vivo (59-61). To begin to investigate the role of NK cell depletion in allogeneic bone marrow transplantation in mice treated with costimulation blockade, BALB/c mice were given anti-CD154 mAb, anti$\mathrm{CD} 122 \mathrm{mAb}$, and $50 \times 10^{6} \mathrm{C} 57 \mathrm{BL} / 6$ bone marrow cells. Surprisingly, hematopoietic chimerism was established in $100 \%$ of these recipients (nine of nine; Table 6 , group 2). This rate of successful engraftment is comparable to that achieved using DST in place of anti-CD122 $\mathrm{mAb}$ (89\%; Table 1, group 1, $P=\mathrm{NS}$ ) and significantly greater than that achieved using anti-CD8 $\mathrm{mAb}$ in place of DST (Table 6, group $1, P<0.01$ ).

Interventions that abrogate peripheral-tolerance induction impair engraftment of bone marrow in mice treated with costimulation blockade

We have previously shown that injection of antiCTLA4 $\mathrm{mAb}$ at the time of peripheral-tolerance induction with DST and anti-CD154 mAb prevents deletion of alloreactive $\mathrm{CD} 8^{+} \mathrm{T}$ cells and shortens skin allograft survival $(35,38)$. Treatment with anti-CD4 $\mathrm{mAb}$ at the time of tolerance induction also shortens skin allograft survival (35). We therefore tested the hypothesis that these interventions would also interfere with the generation of hematopoietic chimerism in bone marrow recipients treated with DST and anti-CD154 mAb. As shown in Table 6 (group 4), treatment with anti$\mathrm{CD} 4 \mathrm{mAb}$ had little effect, and two-thirds of recipients became chimeric, albeit with a level of chimerism that was quite low $(\sim 2.7 \% ; P<0.001$ vs. Table 1 , group 1$)$. Similarly, in a cohort of recipients treated with an anti$\mathrm{CD} 25 \mathrm{mAb}$ known to delete $\mathrm{CD} 4{ }^{+} \mathrm{CD} 25^{+}$regulatory $\mathrm{T}$ cells, nearly all $(89 \%, n=9)$ became chimeric (Table 6 , group 5). In these mice the level of chimerism $(6.0 \%)$ was greater than in the anti-CD4-treated mice $(P<0.005)$, but not as high as in recipients treated with only DST and anti-CD154 mAb ( 9\%; Table 1, group $1, P<0.025)$. Only in the case of treatment with anti-CTLA4 mAb was there a significant reduction in the percentage of mice that became chimeric (22\%; Table 6 , group 3 ). The results suggest that the mechanism by which the combination of DST and anti-CD154 mAb generates 
peripheral transplantation tolerance is distinct but overlaps with the mechanism by which it generates hematopoietic chimerism.

\section{Discussion}

These data demonstrate that a costimulation blockade protocol consisting of a DST plus anti-CD154 $\mathrm{mAb}$ permits allogeneic bone marrow engraftment, the generation of hematopoietic chimerism, and the creation of a state of donor-specific central transplantation tolerance. When combined with minimal myeloablative conditioning, chimerism was achieved in all treated recipients. Doing away with conditioning entirely led to only a modest reduction in the number of mice that were successfully engrafted, and, in those mice that were chimeric, to only a modest reduction in the percentage of donor-origin PBMCs. Even those effects could be overcome in large measure by an increase in the dose of bone marrow cells. Hematopoietic chimerism in mice treated with DST and anti-CD154 $\mathrm{mAb}$ but no conditioning was stable over time, and under all conditions chimeric recipients appeared free of GVHD. Elimination of stringent conditioning holds out the promise of making central-tolerance induction a much safer and more widely applicable clinical tool for transplantation and the treatment of autoimmune disease.

Our data also documented, as expected from previous studies of peripheral-tolerance induction (35), that anti-CD $154 \mathrm{mAb}$ monotherapy in the absence of DST is generally ineffective for generating hematopoietic chimerism. Surprisingly, however, we found that a third-party (MHC-disparate) transfusion could be substituted in some (but not all) cases for the standard DST. The key observation for understanding this counterintuitive result was that an MHC-disparate transfusion was effective only in normal recipients with a physiological (low) percentage of alloreactive $T$ cells. Synchimeric recipients, with their high level of alloreactive $T$ cells, became chimeric only if given a donor-specific transfusion, presumably to reduce that number of alloreactive cells. In a normal $\mathrm{CBA} / \mathrm{J}$ mouse, the number of naturally occurring $\mathrm{T}$ cells with this allospecificity is far fewer, and the requirement for donor specificity of the transfusion was less stringent. In their aggregate, the results suggest that the generation of hematopoietic chimerism using DST and anti-CD154 mAb involves both the deletion of host allospecific $T$ cells and an additional, non-allospecific suppressive mechanism.

The underlying mechanism by which our protocol induces hematopoietic chimerism and central tolerance appears to involve deletion of host alloreactive cells in both the thymus and the periphery of chimeric recipients. Our data provide explicit documentation that $\mathrm{DES}^{+} \mathrm{CD}^{+} \mathrm{CD}^{-}$alloreactive $\mathrm{T}$ cells in the thymus of KB5 synchimeras that were chimeric for C57BL/ 6 hematopoietic cells are deleted. Previous studies have inferred this deletion but have depended on indirect evidence. That evidence was obtained from systems showing intrathymic deletion of host $\mathrm{V} \beta \mathrm{CD} 4^{+} \mathrm{T}$ cells reactive to donor superantigens presented by donor MHC class II I-E antigens $(18,30)$.

Of additional interest is the observation that our peripheral-tolerance protocol, in the absence of bone marrow engraftment, leads to transient deletion of peripheral but not intrathymic alloreactive $\mathrm{CD}^{+} \mathrm{T}$ cells. Previous studies of skin allografts on mice treated with DST and anti-CD154 mAb have shown that graft survival is greatly prolonged, but seldom permanent unless the recipient has been thymectomized (35). The inference has been that the failure of graft maintenance is due to the release of new alloreactive thymic emigrants into the periphery (43). The present results strongly suggest that this inference is correct; they demonstrate that the generation of hematopoietic chimerism in effect "thymectomizes" recipients in a donor-specific manner. The data imply that central tolerance is the essential complement to peripheral-tolerance induction if allografts are to be truly durable.

The long-term durable hematopoietic chimerism we observed is strongly suggestive of a state of donor-specific central tolerance. Consistent with this inference, we also observed donor-specific skin allograft survival in chimeric mice. Disappointingly, however, we noted that three of eight skin allografts were rejected by chimeric hosts. Rejection might have been anticipated in one case, because the recipient had achieved only a low level of chimerism (2\% donor-origin PBMCs), but the other two mice that rejected skin grafts were circulating more than $10 \%$ donor-origin PBMCs. Published studies have reported indefinite skin allograft survival in mice exhibiting 3-6\% donor chimerism $(27,29)$. The reason why the grafts were rejected in the present study is unclear and suggests the need for further study. Speculatively, rejection may have resulted from inefficient intrathymic deletion of donor-reactive $\mathrm{T}$ cells, insufficient production or activation of regulatory $\mathrm{CD}^{+}$cells, expression of skin-specific antigens (62), or graft-specific properties (e.g., chemokine production) that control the inflammatory process and graft rejection (63-66).

To be of value in clinical medicine, transplantation tolerance induction procedures must be generally applicable to a broad range of recipients. It is known that protocols based on peripheral costimulation blockade work to varying degrees depending on the host strain (67). To confirm that the ability of DST plus anti-CD154 mAb to facilitate hematopoietic cell engraftment was not unique to the BALB/c strain, we documented that our protocol can establish hematopoietic cell engraftment in the absence of host conditioning in several mouse strains, each of which was fully MHC-mismatched with its bone marrow donor. Interestingly, all three strains we tested also exhibit prolonged skin allograft survival after treatment with DST plus anti-CD154 mAb (ref. 38; and D.L. Greiner, unpublished observations). 
There are, however, interesting differences among strains in their response to "tolerizing" procedures. In the case of the B10.BR strain, anti-CD154 mAb monotherapy alone can prolong skin allograft survival (D.L. Greiner, unpublished observations), suggesting that this strain is highly susceptible to tolerance induced by costimulation blockade. No other strain is known to exhibit this degree of susceptibility. In contrast, NOD mice are resistant to the induction of peripheral transplantation tolerance by costimulation blockade $(68,69)$, and we have in preliminary studies determined that these mice resist hematopoietic cell engraftment after treatment with DST and anti-CD154 $\mathrm{mAb}$ (E. Seung, unpublished observations). The B10.BR and NOD data suggest that susceptibility to transplantation tolerance may in part be genetically determined. This suggestion is supported by our recent report that NOD mice have a generalized defect in transplantation tolerance induction that is genetically separable from their autoimmune phenotype (70). Susceptibility to peripheral transplantation tolerance appears to be a good predictor of susceptibility to the generation of hematopoietic chimerism and the induction of central tolerance.

An important pragmatic issue relevant to the potential adaptation of our procedures to clinical medicine is our use of an allogeneic bone marrow inoculum that is not $\mathrm{T}$ cell depleted. It is reasonable to ask whether the donor bone marrow in this system requires mature lymphocytes for efficacy, and, if so, whether the protocol could be adapted for humans. The answer to the first question is not known, as we have not tested $\mathrm{T}$ cell-depleted bone marrow cells. We elected not to deplete the bone marrow of $\mathrm{T}$ cells because reports from several laboratories suggest that "facilitator" $\mathrm{T}$ cells may contribute to the establishment of allogeneic hematopoietic chimerism (71-73). In addition, we would point out that the primary reason for $\mathrm{T}$ cell depletion of donor bone marrow in human transplantation is to reduce the risk of GVHD. We and others have shown, however, that anti-CD154 mAb completely prevents GVHD in animal models $(18,22,74)$. Still, whether bone marrow that is not depleted of mature $T$ cells can be used in humans treated with costimulation blockade remains to be determined.

Another pragmatic issue is our employment of a relatively large allogeneic bone marrow dose $\left(50 \times 10^{6}\right)$ in relation to body mass. A large inoculum might arguably increase the risk of GVHD even in the presence of anti-CD154 mAb. The minimum bone marrow inoculum that will achieve hematopoietic chimerism in nonablated mice treated with the protocol described in this study without myeloablation is not known. We did observe, however, that preparative conditioning with $1 \mathrm{~Gy}$ of radiation and $50 \%$ fewer bone marrow cells $\left(25 \times 10^{6}\right)$ did generate robust chimerism, with recipients uniformly circulating about 20\% donor-origin PBMCs. The data suggest that translation of our protocol to humans will require finding an optimal balance between the size of the stem cell inoculum and the intensity of preparative conditioning (if any).

In comparison with published data, the dose of bone marrow cells used in the present study appears relatively modest. One protocol used a single injection of $200 \times 10^{6}$ bone marrow cells (four times larger than our dose) (29). The other protocol used eight injections of $2 \times 10^{7}$ bone marrow cells plus anti-CD154 mAb (27); the total number of bone marrow cells $\left(160 \times 10^{6}\right)$ was approximately three times larger than that used in the present study. Parenthetically, the total dose of anti$\mathrm{CD} 154 \mathrm{mAb}(4 \mathrm{mg})$ in that protocol is four times larger than that used in this study and was given over 3 months rather than 2 weeks. The modest dose of antiCD154 mAb used in our protocol highlights another potentially important pragmatic issue. In human studies, anti-human CD154 mAb administered chronically over long periods of time has been associated with the development of both arterial and venous thrombosis $(75,76)$; this is possibly related to the fact that CD154 is expressed on activated platelets and may stabilize thrombi $(77,78)$. Our protocol requires only a brief 2-week course of treatment with this reagent to achieve a maximum beneficial effect with respect to the generation of chimerism and may avoid this potential therapeutic complication.

Another pragmatic issue relevant to the utility of "multistage" transplantation tolerance induction procedures in clinical medicine is the stringency with which the components of the therapy need to be timed. Interestingly, we observed that our procedures were successful if initiated 1-2 weeks before bone marrow transplantation, but not 5 or fewer days before transplantation. This observation has both clinical and mechanistic implications, as we have previously shown that alloreactive $\mathrm{CD}^{+} \mathrm{T}$ cells disappear from the circulation within 3 days of costimulation blockade (38, 43). This would intuitively suggest that within 3 days of tolerance induction, hosts should be susceptible to hematopoietic stem cell engraftment, but we found that 7 days was the minimum interval between tolerance induction and transplantation in order to achieve chimerism. This result suggested that something more than the deletion of $\mathrm{CD}^{+}$alloreactive $\mathrm{T}$ cells is required for central-tolerance induction, and we obtained evidence that supports this inference.

Replacement of DST with depleting anti-CD8 $\mathrm{mAb}$ in combination with anti-CD154 $\mathrm{mAb}$ prolongs skin allograft survival (38). When applied to bone marrow transplantation, however, this strategy significantly degraded the clinical outcome. Given that $\mathrm{CD}^{+} \mathrm{T}$ cell depletion appeared not to be the entire story, we investigated the potential role of NK cells, which have a major role in the rejection of allogeneic bone marrow cells in lethally irradiated mice (55-58). Our data document that they are important regulators of bone marrow cell engraftment in nonmyeloablated mice treated with costimulation blockade. We combined anti-CD154 
$\mathrm{mAb}$ with anti-CD122 mAb, which is directed against the IL- 2 receptor $\beta$ chain and is expressed on almost all NK cells and on a subpopulation of $\mathrm{CD}^{+} \mathrm{T}$ cells and activated macrophages $(59,79,80)$. Mice treated with this combination therapy could readily be engrafted with allogeneic bone marrow. Because CD154 is also expressed on NK cells, we hypothesize that engraftment of allogeneic bone marrow cells in nonmyeloablated hosts requires not only the deletion of alloreactive $\mathrm{CD}^{+} \mathrm{T}$ cells, but also inactivation of host NK cells. Alternatively, failure of anti-CD154 mAb plus antiCD8 $\mathrm{mAb}$ therapy to induce high levels of chimerism may result from the ability of anti-CD $8 \mathrm{mAb}$ to delete not only the endogenous population of $\mathrm{CD}^{+}$cells, but also the exogenous population present in the donor bone marrow. Several laboratories have reported the existence of "facilitator" cells, a rare donor-origin $\mathrm{CD}^{+}$ bone marrow subpopulation that can enhance allogeneic hematopoietic stem cell engraftment (71-73). Anti-CD8 mAb in the host may be deleting donor facilitator cells required for stem cell engraftment in a nonmyeloablated host.

These data on the role of $\mathrm{CD}^{+}$cells in transplantation tolerance clearly indicate that the mechanisms responsible for peripheral-tolerance induction and the generation of hematopoietic chimerism are overlapping but different. Another distinction between the two relates to the $\mathrm{CD}^{+}$cell populations. Treatment with anti-CD4 $\mathrm{mAb}$ prevents the induction of peripheral transplantation tolerance by DST plus anti-CD $154 \mathrm{mAb}(35,43)$. In contrast, the addition of anti-CD4 $\mathrm{mAb}$ to our chimerism protocol did not prevent hematopoietic engraftment, although it did reduce the level of chimerism.

Our surprising discovery that the priming transfusion given after the first injection of anti-CD154 mAb need not be MHC-matched with the eventual bone marrow donor (i.e., it need not be "donor specific") has important clinical and theoretical implications. The clinical implication is obvious. The ability to obtain and deliver to a recipient a DST, bone marrow graft, and an organ for transplantation is greatly simplified per our observation that the DST and bone marrow need not be from the same donor.Mechanistically, the kinetics of susceptibility to engraftment may relate to the ability of a non-allo-matched DST to induce a "nonspecific" regulatory mechanism(s) that facilitates the process. There is an extensive literature on the effects of donor-lymphocyte transfusion as a means of enhancing allograft survival. Proposed mechanisms include establishment of mixed allogeneic chimerism $(81,82)$, deletion of donor-reactive T cells (38, 43, 83-85), induction of clonal anergy (86), cytokine production (87), and the generation of regulatory $\mathrm{T}$ cells $(35,43,88,89)$.

An additional possibility is the induction of tolerogenic dendritic cells (90-93) and/or the production of regulatory cytokines by an immune system activated in the presence of anti-CD154 mAb. Dendritic cells that ingest apoptotic cells (94) (as the DST is eliminated) or become activated in the presence of CD40-CD154 blockade appear to become tolerogenic cells that suppress immune responses and secrete regulatory cytokines such as TGF- $\beta$ and IL-10 $(95,96)$. Alternatively, the requirement for the 7-day delay after DST for bone marrow engraftment to occur may be due to delayed deletion of host alloreactive T cells. It is known that fully activated $\mathrm{CD} 8^{+} \mathrm{T}$ cells migrate to nonlymphoid tissues, where they become memory cells (97, 98). Incomplete activation in the presence of CD40CD154 blockade may induce migration and initiate apoptosis of antigen-activated $\mathrm{T}$ cells that could be reversed if a second allo-stimulus in the form of allogeneic bone marrow is given too soon after DST.

In conclusion, we have demonstrated that procedures originally designed for the induction of peripheral transplantation tolerance can be adapted to permit allogeneic bone marrow cell engraftment and the generation of hematopoietic chimerism. The results further suggest that there is commonality to the generation of peripheral and central tolerance and that the maintenance of transplantation tolerance will require either physical thymectomy or its biological equivalent -central-tolerance induction. The procedures do not require host myeloablative conditioning, appear not to lead to GVHD, and may not necessarily require MHCmatching of transfusion, bone marrow, and donor organs - characteristics that make these procedures highly attractive for translation to clinical medicine.

\section{Acknowledgments}

This work was supported in part by NIH grant AI42669; by an institutional Diabetes Endocrinology Research Center grant, DK-52530, from the NIH; and by grant DK-53006, jointly funded by the NIH and the Juvenile Diabetes Research Foundation. The contents of this publication are solely the responsibility of the authors and do not necessarily represent the official views of the NIH.

\footnotetext{
1. Appelbaum, F.R. 2001. Haematopoietic cell transplantation as immunotherapy. Nature. 411:385-389.

2. Leykin, I., Nikolic, B., and Sykes, M. 2001. Mixed bone marrow chimerism as a treatment for autoimmune diabetes. Transplant. Proc. 33:120.

3. Slavin, S., et al. 2001. Nonmyeloablative stem cell transplantation for the treatment of cancer and life-threatening nonmalignant disorders: past accomplishments and future goals. Cancer Chemother. Pharmacol. 48(Suppl. 1):S79-S84

4. Solsky, M.A., and Wallace, D.J. 2002. New therapies in systemic lupus erythematosus. Best Pract. Res. Clin. Rheumatol. 16:293-312.

5. Openshaw, H., Nash, R.A., and McSweeney, P.A. 2002. High-dose immunosuppression and hematopoietic stem cell transplantation in autoimmune disease: clinical review. Biol. Blood Marrow Transplant. 8:233-248.

6. Yang, K.D., and Hill, H.R. 2001. Granulocyte function disorders: aspects of development, genetics and management. Pediatr. Infect. Dis. J. 20:889-900.

7. Poulsom, R., Alison, M.R., Forbes, S.J., and Wright, N.A. 2002. Adult stem cell plasticity. J. Pathol. 197:441-456.

8. Bordignon, C., and Roncarolo, M.G. 2002. Therapeutic applications for hematopoietic stem cell gene transfer. Nat. Immunol. 3:318-321.

9. Emery, D.W., Nishino, T., Murata, K., Fragkos, M., and Stamatoyannopoulos, G. 2002. Hematopoietic stem cell gene therapy. Int. J. Hematol. 75:228-236
} 
10. Park, K.I., et al. 2002. Global gene and cell replacement strategies via stem cells. Gene Ther 9:613-624.

11. Desnick, R.J., and Astrin, K.H. 2002. Congenital erythropoietic porphyria: advances in pathogenesis and treatment. Br. J. Haematol. 117:779-795.

12. Bielorai, B., Golan, H., Rechavi, G., and Toren, A. 2002. Stem-cell transplantation for primary immunodeficiencies. Isr. Med. Assoc. J. 4:648-652.

13. Rossini, A.A., Greiner, D.L., and Mordes, J.P. 1999. Induction of immunological tolerance for transplantation. Physiol. Rev. 79:99-141.

14. Sorli, C.H., Greiner, D.L., Mordes, J.P., and Rossini, A.A. 1998. Stem cell transplantation for treatment of autoimmune diseases. Graft: Organ and Cell Transplantation. 1:71-81.

15. Locatelli, F., Rondelli, D., and Burgio, G.R. 2000. Tolerance and hematopoietic stem cell transplantation 50 years after Burnet's theory. Exp. Hematol. 28:479-489.

16. Giralt, S., et al. 1997. Engraftment of allogeneic hematopoietic progenitor cells with purine analog-containing chemotherapy: harnessing graft-versus-leukemia without myeloablative therapy. Blood. 89:4531-4536.

17. Anderlini, P., et al. 2000. Allogeneic stem cell transplantation with fludarabine-based, less intensive conditioning regimens as adoptive immunotherapy in advanced Hodgkin's disease. Bone Marrow Transplant. 26:615-620.

18. Sykes, M. 2001. Mixed chimerism and transplant tolerance. Immunity. 14:417-424.

19. Laederach-Hofmann, K., and Bunzel, B. 2000. Noncompliance in organ transplant recipients: a literature review. Gen. Hosp. Psychiatry. 22:412-424

20. Soulillou, J.P., and Giral, M. 2001. Controlling the incidence of infection and malignancy by modifying immunosuppression. Transplantation. 72(Suppl. 12):S89-S93.

21. Forman, D., et al. 2002. Viral abrogation of stem cell transplantation tolerance causes graft rejection and host death by different mechanisms. J. Immunol. 168:6047-6056.

22. Seung, E., et al. 2000. Allogeneic hematopoietic chimerism in mice treated with sublethal myeloablation and anti-CD154 antibody: absence of graft-versus-host disease, induction of skin allograft tolerance, and prevention of recurrent autoimmunity in islet-allografted NOD/Lt mice. Blood. 95:2175-2182.

23. Wekerle, T., et al. 2001. Peripheral deletion after bone marrow transplantation with costimulatory blockade has features of both activationinduced cell death and passive cell death. J. Immunol. 166:2311-2316.

24. Wekerle, T., et al. 1998. Extrathymic T cell deletion and allogeneic stem cell engraftment induced with costimulatory blockade is followed by central T cell tolerance. J. Exp. Med. 187:2037-2044.

25. Adams, A.B., et al. 2001. Costimulation blockade, busulfan, and bone marrow promote titratable macrochimerism, induce transplantation tolerance, and correct genetic hemoglobinopathies with minimal myelosuppression. J. Immunol. 167:1103-1111.

26. Taylor, P.A., Lees, C.J., Waldmann, H., Noelle, R.J., and Blazar, B.R. 2001 Requirements for the promotion of allogeneic engraftment by antiCD154 (anti-CD40L) monoclonal antibody under nonmyeloablative conditions. Blood. 98:467-474.

27. Durham, M.M., et al. 2000. Cutting edge: Administration of anti-CD40 ligand and donor bone marrow leads to hemopoietic chimerism and donor-specific tolerance without cytoreductive conditioning. J. Immunol. 165:1-4.

28. Kean, L.S., et al. 2002. A cure for murine sickle cell disease through stable mixed chimerism and tolerance induction after nonmyeloablative conditioning and major histocompatibility complex-mismatched bone marrow transplantation. Blood. 99:1840-1849.

29. Wekerle, T., et al. 2000. Allogeneic bone marrow transplantation with costimulatory blockade induces macrochimerism and tolerance without cytoreductive host treatment. Nat. Med. 6:464-469.

30. Wekerle,T., and Sykes, M. 2001. Mixed chimerism and transplantation tolerance. Annu. Rev. Med. 52:353-370.

31. Guinan, E.C., et al. 1999. Transplantation of anergic histoincompatible bone marrow allografts. N. Engl. J. Med. 340:1704-1714.

32. Adams, A.B., Pearson, T.C., and Larsen, C.P. 2001. Conventional immunosuppression and co-stimulation blockade. Philos. Trans. R. Soc. Lond. B Biol. Sci. 356:703-705.

33. Parker, D.C., et al. 1995. Survival of mouse pancreatic islet allografts in recipients treated with allogeneic small lymphocytes and antibody to CD40 ligand. Proc. Natl. Acad. Sci. U. S. A. 92:9560-9564.

34. Markees, T.G., et al. 1998. Improved skin allograft tolerance induced by treatment with donor splenocytes and an extended course of antiCD154 monoclonal antibody. Transplant. Proc. 30:2444-2446.

35. Markees, T.G., et al. 1998. Long-term survival of skin allografts induced by donor splenocytes and anti-CD154 antibody in thymectomized mice requires $\mathrm{CD}^{+} \mathrm{T}$ cells, interferon-gamma, and CTLA4. J. Clin. Invest. 101:2446-2455.
36. Markees, T.G., et al. 1997. Prolonged survival of mouse skin allografts in recipients treated with donor splenocytes and antibody to CD40 ligand. Transplantation. 64:329-335.

37. Elster, E.A., et al. 2001. Treatment with the humanized CD154-specific monoclonal antibody, hu5C8, prevents acute rejection of primary skin allografts in nonhuman primates. Transplantation. 72:1473-1478.

38. Iwakoshi, N.N., et al. 2000. Treatment of allograft recipients with donor specific transfusion and anti-CD154 antibody leads to deletion of alloreactive $\mathrm{CD}^{+} \mathrm{T}$ cells and prolonged graft survival in a CTLA4-dependent manner. J. Immunol. 164:512-521.

39. Ito, H., Kurtz, J., Shaffer, J., and Sykes, M. 2001. CD4 T cell-mediated alloresistance to fully MHC-mismatched allogeneic bone marrow engraftment is dependent on CD40-CD40 ligand interactions, and lasting $\mathrm{T}$ cell tolerance is induced by bone marrow transplantation with initial blockade of this pathway. J. Immunol. 166:2970-2981.

40. Wekerle, T., et al. 1999. Anti-CD154 or CTLA4lg obviates the need for thymic irradiation in a non-myeloablative conditioning regimen for the induction of mixed hematopoietic chimerism and tolerance. Transplantation. 68:1348-1355.

41. Tafuri, A., Alferink, J., Möller, P., Hämmerling, G.J., and Arnold, B. 1995. $\mathrm{T}$ cell awareness of paternal alloantigens during pregnancy. Science. 270:630-633.

42. Kearney, E.R., Pape, K.A., Loh, D.Y., and Jenkins, M.K. 1994. Visualization of peptide-specific $\mathrm{T}$ cell immunity and peripheral tolerance induction in vivo. Immunity. 1:327-339.

43. Iwakoshi, N.N., et al. 2001. Skin allograft maintenance in a new synchimeric model system of tolerance. J. Immunol. 167:6623-6630.

44. Noelle, R.J., et al. 1992. A 39-kDa protein on activated helper T cells binds CD40 and transduces the signal for cognate activation of B cells. Proc. Natl. Acad. Sci. U. S. A. 89:6550-6554.

45. Foy, T.M., et al. 1993. In vivo CD40-gp39 interactions are essential for thymus- dependent humoral immunity. II. Prolonged suppression of the humoral immune response by an antibody to the ligand for CD40, gp39. J. Exp. Med. 178:1567-1575.

46. Nie, N.H., Hull, C.H., Jenkins, J.G., Steinbrenner, K., and Bent, D.H. 1975. Statistical package for the social sciences. McGraw-Hill. New York, New York, USA. 675 pp.

47. Glantz, S.A. 1981. Primer of biostatistics. McGraw-Hill. New York, New York, USA. 352 pp.

48. Siegel, S. 1956. Nonparametric statistics. McGraw-Hill. New York, New York, USA. 239 pp.

49. Kaplan, E.L., and Meier, P. 1958. Nonparametric estimation from incomplete observations. J. Am. Stat. Assoc. 53:457-481.

50. Matthews, D.E., and Farewell, V.T. 1988. The log-rank or Mantel-Haenszel test for the comparison of survival curves. In Using and understanding medical statistics. D.E. Matthews and V.T. Farewell, editors. Karger. Basel, Switzerland. 79-87.

51. Manilay, J.O., Pearson, D.A., Sergio, J.J., Swenson, K.G., and Sykes, M. 1998. Intrathymic deletion of alloreactive T cells in mixed bone marrow chimeras prepared with a nonmyeloablative conditioning regimen. Transplantation. 66:96-102.

52. Mathieson, B.J., and Fowlkes, B.J. 1984. Cell surface antigen expression on thymocytes: development and phenotypic differentiation of intrathymic subsets. Immunol. Rev. 82:141-173.

53. Shortman, K., Scollay, R., Andrews, P., and Boyd, R. 1986. Development of T lymphocytes within the thymus and within thymic nurse cells. Curr. Top. Microbiol. Immunol. 126:5-18.

54. Ceredig, R., and Cummings, D.E. 1983. Phenotypic and functional properties of murine thymocytes. III. Kinetic analysis of the recovery of intrathymic cytolytic T lymphocyte precursors after in vivo administration of hydrocortisone acetate. J. Immunol. 130:33-37.

55. Yu, Y.Y., Kumar, V., and Bennett, M. 1992. Murine natural killer cells and marrow graft rejection. Annu. Rev. Immunol. 10:189-213.

56. Murphy, W.J., Reynolds, C.W., Tiberghien, P., and Longo, D.L. 1993. Natural killer cells and bone marrow transplantation. J. Natl. Cancer Inst. 85:1475-1482.

57. Murphy, W.J., Kumar, V., and Bennett, M. 1987. Rejection of bone marrow allografts by mice with severe combined immune deficiency (SCID). Evidence that natural killer cells can mediate the specificity of marrow graft rejection. J. Exp. Med. 165:1212-1217.

58. Cudkowicz, G., and Bennett, M. 1971. Peculiar immunobiology of bone marrow allografts. I. Graft rejection by irradiated responder mice. J. Exp. Med. 134:83-102.

59. Tanaka, T., et al. 1991. A novel monoclonal antibody against murine IL-2 receptor beta-chain. Characterization of receptor expression in normal lymphoid cells and EL-4 cells. J. Immunol. 147:2222-2228.

60. Tanaka, T., et al. 1993. Selective long-term elimination of natural killer cells in vivo by an anti-interleukin 2 receptor beta-chain monoclonal antibody in mice. J. Exp. Med. 178:1103-1107.

61. Ehl, S., et al. 1996. A comparison of efficacy and specificity of three NK depleting antibodies. J. Immunol. Methods. 199:149-153. 
62. Steinmuller, D. 1998. The enigma of skin allograft rejection. Transplant. Rev. 12:42-57.

63. Abdi, R., et al. 2002. The role of CC chemokine receptor 5 (CCR5) in islet allograft rejection. Diabetes. 51:2489-2495.

64. Hancock, W.W., et al. 2001. Donor-derived IP-10 initiates development of acute allograft rejection. J. Exp. Med. 193:975-980.

65. Dufour, J.H., et al. 2002. IFN-gamma-inducible protein 10 (IP-10; CXCL10)-deficient mice reveal a role for IP-10 in effector T cell generation and trafficking. J. Immunol. 168:3195-3204.

66. Zhao, D.X., et al. 2002. Differential expression of the IFN-gammainducible CXCR3-binding chemokines, IFN-inducible protein 10, monokine induced by IFN, and IFN-inducible T cell alpha chemoattractant in human cardiac allografts: association with cardiac allograft vasculopathy and acute rejection. J. Immunol. 169:1556-1560.

67. Williams, M.A., et al. 2000. Genetic characterization of strain differences in the ability to mediate CD40/CD28-independent rejection of skin allografts. J. Immunol. 165:6849-6857.

68. Markees, T.G., et al. 1999. NOD mice have a generalized defect in their response to transplantation tolerance induction. Diabetes. 48:967-974.

69. Molano, R.D., et al. 2001. Prolonged islet graft survival in NOD mice by blockade of the CD40-CD154 pathway of T-cell costimulation. Diabetes. 50:270-276.

70. Pearson, T., et al. 2003. NOD congenic mice genetically protected from autoimmune diabetes remain resistant to transplantation tolerance induction. Diabetes. 52:321-326.

71. Schuchert, M.J., Wright, R.D., and Colson, Y.L. 2000. Characterization of a newly discovered T-cell receptor beta-chain heterodimer expressed on a $\mathrm{CD}^{+}$bone marrow subpopulation that promotes allogeneic stem cell engraftment. Nat. Med. 6:904-909.

72. Kaufman, C.L., et al. 1994. Phenotypic characterization of a novel bone marrow-derived cell that facilitates engraftment of allogeneic bone marrow stem cells. Blood. 84:2436-2446.

73. Fowler, D.H., Whitfield, B., Livingston, M., Chrobak, P., and Gress, R.E. 1998. Non-host-reactive donor $\mathrm{CD}^{+} \mathrm{T}$ cells of Tc2 phenotype potently inhibit marrow graft rejection. Blood. 91:4045-4050.

74. Durie, F.H., et al. 1994. Antibody to the ligand of CD40, gp39, blocks the occurrence of the acute and chronic forms of graft-vs-host disease. J. Clin. Invest. 94:1333-1338.

75. Buhler, L., Alwayn, I.P., Appel, J.Z., III, Robson, S.C., and Cooper, D.K 2001. Anti-CD154 monoclonal antibody and thromboembolism. Transplantation. 71-491.

76. Kawai, T., Andrews, D., Colvin, R.B., Sachs, D.H., and Cosimi, A.B. 2000 Thromboembolic complications after treatment with monoclonal antibody against CD40 ligand. Nat. Med. 6:114.

77. Henn, V., et al. 1998. CD40 ligand on activated platelets triggers an inflammatory reaction of endothelial cells. Nature. 391:591-594.

78. André, P., et al. 2002. CD40L stabilizes arterial thrombi by a $\beta_{3}$ integrin-dependent mechanism. Nat. Med. 8:247-252.

79. Ohashi, Y., Takeshita, T., Nagata, K., Mori, S., and Sugamura, K. 1989. Differential expression of the IL-2 receptor subunits, p55 and p75 on various populations of primary peripheral blood mononuclear cells J. Immunol. 143:3548-3555.

80. Allouche, M., et al. 1990. Interleukin 2 receptors. Lenk. Res. 14:699-703.

81. Sykes, M. 2001. Mixed chimerism and transplant tolerance. Immunity. 14:417-424.

82. de Waal, L.P., and van Twuyver, E. 1991. Blood transfusion and allograft survival: is mixed chimerism the solution for tolerance induction in clinical transplantation? Crit. Rev. Immunol. 10:417-425.

83. Li,Y., et al. 1999. Blocking both signal 1 and signal 2 of T-cell activation prevents apoptosis of alloreactive $T$ cells and induction of peripheral allograft tolerance. Nat. Med. 5:1298-1302.

84. Wells, A.D., et al. 1999. Requirement for T-cell apoptosis in the induction of peripheral transplantation tolerance. Nat. Med. 5:1303-1307.

85. Trambley, J., et al. 1999 . Asialo $\mathrm{GM}^{+} \mathrm{CD}^{+} \mathrm{T}$ cells play a critical role in costimulation blockade-resistant allograft rejection. J. Clin. Invest. 104:1715-1722.

86. Dallman, M.J., Shiho, O., Page, T.H., Wood, K.J., and Morris, P.J. 1991. Peripheral tolerance to alloantigen results for altered regulation of the interleukin 2 pathway. J. Exp. Med. 173:79-87.

87. Josien, R., et al. 1995. Graft-infiltrating T helper cells, CD45RC phenotype, and Th1/Th2- related cytokines in donor-specific transfusioninduced tolerance in adult rats. Transplantation. 60:1131-1139.

88. Yang, L., Du, T.B., Khan, Q., and Zhang, L. 1998. Mechanisms of longterm donor-specific allograft survival induced by pretransplant infusion of lymphocytes. Blood. 91:324-330.

89. Vignes, C., et al. 2000. Anti-TCR-specific DNA vaccination demonstrates a role for $\mathrm{a} \mathrm{CD}^{+} \mathrm{T}$ cell clone in the induction of allograft tolerance by donor-specific blood transfusion. J. Immunol. 165:96-101.

90. Homann, D., et al. 2002. CD40L blockade prevents autoimmune diabetes by induction of bitypic NK/DC regulatory cells. Immunity. 16:403-415.

91. Grohmann, U., et al. 2001. CD40 ligation ablates the tolerogenic potential of lymphoid dendritic cells. J. Immunol. 166:277-283.

92. Hawiger, D., et al. 2001. Dendritic cells induce peripheral T cell unresponsiveness under steady state conditions in vivo. J. Exp. Med. 194:769-779

93. Miga, A.J., et al. 2001. Dendritic cell longevity and T cell persistence is controlled by CD154-CD40 interactions. Eur. J. Immunol. 31:959-965.

94. Stuart, L.M., et al. 2002. Inhibitory effects of apoptotic cell ingestion upon endotoxin-driven myeloid dendritic cell maturation. J. Immunol. 168: $1627-1635$

95. Hara, M., et al. 2001. IL-10 is required for regulatory T cells to mediate tolerance to alloantigens in vivo. J. Immunol. 166:3789-3796.

96. Zeller, J.C., et al. 1999. Induction of $\mathrm{CD}^{+} \mathrm{T}$ cell alloantigen-specific hyporesponsiveness by IL-10 and TGF- $\beta$. J. Immunol. 163:3684-3691.

97. Lefrancois, L., and Masopust, D. 2002. T cell immunity in lymphoid and non-lymphoid tissues. Curr. Opin. Immunol. 14:503-508.

98. Kim, S.K., Reed, D.S., Heath, W.R., Carbone, F., and Lefrancois, L. 1997. Activation and migration of CD8 $\mathrm{T}$ cells in the intestinal mucosa. J. Immunol. 159:4295-4306. 